\title{
Surface treatments and functionalization of metalceramic membranes for improved enzyme immobilization performance
}

Zeuner, B.; Ovtar, Simona; Persson, Å. H.; Foghmoes, S. P. V.; Berendt, K.; Ma, N.; Kaiser, A.; Della Negra, M.; Pinelo, M.

Published in:

Journal of Chemical Technology and Biotechnology

Link to article, DOI:

$10.1002 / j c t b .6278$

Publication date:

2020

Document Version

Peer reviewed version

Link back to DTU Orbit

Citation (APA):

Zeuner, B., Ovtar, S., Persson, Å. H., Foghmoes, S. P. V., Berendt, K., Ma, N., Kaiser, A., Della Negra, M., \& Pinelo, M. (2020). Surface treatments and functionalization of metalceramic membranes for improved enzyme immobilization performance. Journal of Chemical Technology and Biotechnology, 95(4), 993-1007.

https://doi.org/10.1002/jctb.6278

\section{General rights}

Copyright and moral rights for the publications made accessible in the public portal are retained by the authors and/or other copyright owners and it is a condition of accessing publications that users recognise and abide by the legal requirements associated with these rights.

- Users may download and print one copy of any publication from the public portal for the purpose of private study or research.

- You may not further distribute the material or use it for any profit-making activity or commercial gain

- You may freely distribute the URL identifying the publication in the public portal 


\section{Surface treatments and functionalization of metal-ceramic membranes for improved enzyme immobilization performance}

Short title: Enzyme immobilization in metal-ceramic membranes

${ }^{1}$ Center for Bioprocess Engineering, Department of Chemical and Biochemical Engineering, Technical University of Denmark, Building 229, DK-2800 Kgs. Lyngby; ${ }^{2}$ Department of Energy Conversion and Storage, Technical University of Denmark, Frederiksborgvej 399, DK-4000 Roskilde.

*Corresponding author: mp@kt.dtu.dk

Email addresses: bzeu@dtu.dk (B. Zeuner), simona.ovtar@gmail.com (S. Ovtar), aase@dtu.dk (Å. H. Persson), sqfo@dtu.dk (S. Foghmoes), kasper_b@youmail.dk (K. Berendt), pudidotdk@gmail.com (N. Ma), akai@dtu.dk (A. Kaiser), michela.dellanegra@carlsberg.com (M. Della Negra), mp@kt.dtu.dk (M. Pinelo)

\section{Abstract}

BACKGROUND: Enzyme immobilization in porous membranes often improves enzyme performance. This work reports the preparation and characterization of robust and scalable asymmetric metal-ceramic microfiltration membrane. The surface of the porous metal-ceramic membrane was treated by impregnation with a ceramic

This article has been accepted for publication and undergone full peer review but has not been through the copyediting, typesetting, pagination and proofreading process which may lead to differences between this version and the Version of Record. Please cite this article as doi: 10.1002/jctb.6278 
oxide for enzyme adsorption and corrosion protection. Finally, enzyme immobilization in the support was investigated.

RESULTS: The bilayer membrane was successfully fabricated by combining a ceramic microfiltration layer with a metal support by tape casting, lamination and co-sintering. A pore size in the ceramic microfiltration layer of 0.4 $\mu \mathrm{m}$ resulted in high water permeability $\left(12000 \mathrm{~L} /\left(\mathrm{m}^{2} \mathrm{~h}\right.\right.$ bar $\left.)\right)$. Two different surface treatments were compared: heat treatment and $\mathrm{Y}_{2} \mathrm{O}_{3}$ impregnation. Corrosion stability tests under enzyme-relevant conditions gave no detectable chemical or structural changes. Alcohol dehydrogenase (EC 1.1.1.1) was immobilized in the membrane by physical adsorption and by two covalent immobilization methods. Covalent immobilization significantly improved enzyme loading, activity, and recyclability. Membrane reuse by heat treatment removed fouling, but decreased immobilization performance.

CONCLUSION: The improved microstructure obtained by $\mathrm{Y}_{2} \mathrm{O}_{3}$-impregnation had a significant effect on enzyme loading yield and activity. This indicates the potential of this surface modification method and of these metalsupported ceramic membranes in enzyme immobilization. Covalent immobilization was superior.

Keywords: metal-ceramic membranes, alcohol dehydrogenase, enzyme immobilization, chromia scale, yttria surface modification, membrane reuse

\section{Introduction}

Enzymatic membrane reactors (EMRs) have been studied and successfully employed in the past decades for enzyme recovery and product separation in biocatalytic reactions. ${ }^{1-3}$ Numerous publications have also proven the advantages of enzyme immobilization in porous membranes, where the pores act as micro-reactors and the substrate is transformed into products when it comes into contact with the immobilized enzyme. ${ }^{4}$ Besides the possibility of operating in continuous mode and easy scale-up, the EMR allows control of the reaction rates and kinetics. Moreover, a more protected environment for the enzyme and controlled conditions may prolong the biocatalyst lifetime and its activity. ${ }^{2}$ In this context, the use of inorganic membranes as support for enzymatic reactions offers the additional advantage of a prolonged membrane lifetime. Appropriately chosen inorganic mombrane materials are chemically and mechanically stable, and therefore resistant and durable even when subjected to the harsh conditions used during the reactor cleaning procedures (high temperature, fouling removal and disinfection). ${ }^{5,6}$ Furthermore, the mechanical strength of the membrane layer ensures that the membrane pore size is not changed under high pressure, backwashing or even in supercritical conditions.

The most commonly investigated inorganic membrane materials are alumina, zirconia, silica and titania. Metal supported ceramic membranes represent an interesting alternative because of their significantly improved toughness, lower brittleness, and for the opportunity of welding or brazing. Recent research in this field shows the possibility of producing ceramic-metallic composite microporous membranes for filtration applications. ${ }^{7-10}$ It is worth noting that a porous stainless steel with a large and irregular surface area is exposed to corrosion and corrosion rates are larger than those reported for dense layers. ${ }^{11}$ In the current work, two approaches were 
pursued to achieve corrosion protection of FeCr-based metal alloys: heat treatment and impregnation with yttrium $(\mathrm{Y})$ salts to form a protective oxide. The corrosion resistance of $\mathrm{FeCr}$-based metal alloys strongly depends on the heat treatment temperature: above $700^{\circ} \mathrm{C}$, heat treatments promote the formation of a continuous chromium oxide $\left(\mathrm{Cr}_{2} \mathrm{O}_{3}\right)$ scale that functions as an effective corrosion protection layer; below $700^{\circ} \mathrm{C}$ a FeCr-spinel scale with lower protection performance forms. ${ }^{12}$ Furthermore, it has been shown that yttrium oxide $\left(\mathrm{Y}_{2} \mathrm{O}_{3}\right)$ and other metal oxides (e.g. Ti, Ce, La or Zr) provide corrosion protection. ${ }^{13}$

To investigate the performance of the developed metal-ceramic membranes as supports for enzyme immobilization, alcohol dehydrogenase (ADH; EC 1.1.1.1) was used as a model enzyme. ADH has been investigated as part of a three-step enzymatic cascade for production of methanol $\left(\mathrm{CH}_{3} \mathrm{OH}\right)$ from $\mathrm{CO}_{2}$. Using NADH as co-factor, ADH catalyzes the reduction of formaldehyde to methanol which is the last reaction in this designed three-step cascade reaction. ${ }^{14}$ The commercially available ADH enzyme from Saccharomyces cerevisiae yeast is not a very stable enzyme for industrial use. Thus, various enzyme immobilization techniques have been investigated for enhanced enzyme stability and efficiency of this three-step cascade. ${ }^{15,16}$ While free ADH lost its activity completely within 2 hours of reaction, the biocatalytic productivity of ADH immobilized by physical adsorption on a polysulphone/polypropylene membrane was $73 \%$ of the original even after five 30 -minute reaction cycles. ${ }^{17}$ In another study, $\mathrm{ADH}$ became more robust towards changes in $\mathrm{pH}$ and temperature upon immobilization on alginate-chitosan beads cross-linked with glutaraldehyde (GA). ${ }^{18}$

In this work, metal-supported ceramic membranes were fabricated and optimized according to cheap, robust, and scalable fabrication processes, namely tape casting, lamination and co-sintering under reducing atmosphere. The success criterion for the development of the membrane structure was to achieve a reproducible and scalable multilayer membrane fabrication method with high water permeability without optimization of the actual enzyme separation. The resulting membrane consisted of a stainless steel metal support layer and an yttria-stabilized zirconia (YSZ) ceramic layer (Figure 1). Two surface modification methods were tested for corrosion protection. Enzyme immobilization by physical adsorption was tested on the best membrane candidates obtained. The surface modification is likely to affect not only corrosion but also enzyme immobilization as recently shown for organic polymeric membranes. ${ }^{19}$ In addition to physical adsorption, which is the simplest immobilization method, two different immobilization techniques were examined: 1) coating of the membranes with polyethylenimine (PEI) followed by glutaraldehyde (GA) activation and subsequent covalent attachment of the enzyme, and 2) grafting of the YSZ and stainless steel surfaces with (3aminopropyl)triethoxysilane (APTES) followed by GA activation and covalent enzyme attachment. Especially the latter method is commonly used for enzyme immobilization on inorganic supports. ${ }^{6}$ Finally, reuse of the metalceramic membranes was tested in an explorative study, where the used membranes were heat-treated at $350^{\circ} \mathrm{C}$ to remove organics and reused for ADH immobilization. 


\section{Materials and methods}

\section{Materials and membrane design}

Metal-ceramic membranes were prepared by tape casting, ${ }^{20}$ lamination and co-sintering. The two porous tapes were casted separately: a stainless steel layer used a support and an YSZ ceramic layer as a microporous membrane layer. The metal support slurry consisted of 59 wt\% $\mathrm{Fe}_{22} \mathrm{Cr}$ fraction $-38 \mu \mathrm{m}$ (Sandvik Osprey Ltd, UK), 8 wt $\%$ graphite fractions $d_{50}=8.5-11 \mu \mathrm{m}$ and $d_{50}=9-14 \mu \mathrm{m}$ (Graphit Kropfmühl GmbH, Germany), 6 wt $\%$ ethanol, and $27 \mathrm{wt} \%$ polyvinyl butyral (PVB) binder system. The ceramic slurry consisted of $30 \mathrm{wt} \%$ 8YSZ BET fraction 16 $\mathrm{m}^{2} / \mathrm{g}$ (Tosoh, Japan), $11 \mathrm{wt} \%$ poly(methyl methacrylate (PMMA) fraction $1.8 \mu \mathrm{m}$ (MX 180TA, Esprix Technologies, USA), $32 \mathrm{wt} \%$ isopropyl alcohol, $5 \mathrm{wt} \% \mathrm{PEl}$ dissolved in isopropyl alcohol (0.22 $\mathrm{g} / \mathrm{g}$ ratio) and $29 \mathrm{wt} \% \mathrm{PVB}$ solution. The ceramic slurry was ball-milled for $72 \mathrm{~h}$ until $d_{50}=0.15 \mu \mathrm{m}$. The metal slurry was only ball-milled for $24 \mathrm{~h}$. $\mathrm{A}$ double doctor-blade system was used for tape casting and the casting height was controlled to prepare tapes with different thicknesses. The final membrane was prepared by laminating the two tapes together in a double roll lamination at $130^{\circ} \mathrm{C}$ before it was de-binded in air followed by sintering in reducing atmosphere at temperatures between $1100^{\circ} \mathrm{C}$ and $1300^{\circ} \mathrm{C}$. The resulting sintered samples were squares of $140 \times 140 \mathrm{~mm}^{2}$ without cracks or any deformation; only a few $\mathrm{mm}$ were slightly curled at the plate edge, giving an actual useful membrane surface area of $120 \times 120 \mathrm{~mm}^{2}$. In order to fit the equipment available for gas and water permeability measurements and enzyme immobilization testing, smaller circular pieces with a diameter of $25 \mathrm{~mm}$ were laser cut from the membranes after sintering. For future applications, the full membrane area could be employed.

\section{Surface treatments}

Two different routes were considered to improve corrosion resistance, water permeability and enzyme immobilization performance of the metal-ceramic membrane: i) Growth of $\mathrm{a}_{2} \mathrm{O}_{3}$ layer with heat treatment and ii) introduction of $\mathrm{Y}_{2} \mathrm{O}_{3}$ oxide coating by impregnation. The heat treatment was performed at $800^{\circ} \mathrm{C}$ for 2 hours in air, which induced a controlled oxidation of the metal surface to form $\mathrm{Cr}_{2} \mathrm{O}_{3}$ scales (these samples are further named as $\mathrm{C}-\mathrm{HT} 800$, where $\mathrm{C}-\mathrm{HT} 800$ means ceramic membrane heat-treated at $800^{\circ} \mathrm{C}$ ). The $\mathrm{Y}_{2} \mathrm{O}_{3}$ coating on the surface of the metal support and the YSZ layer was produced through impregnation with $\mathrm{Y}_{\left(\mathrm{NO}_{3}\right)_{3}}$ (purity $00.8 \%$, Sigma-Aldrich, Germany) in aqueous solution. The following heat treatment at $350^{\circ} \mathrm{C}$ ensured the degradation of the nitrate with oxide formation. The samples with $\mathrm{Y}_{2} \mathrm{O}_{3}$ coating are further named as $\mathrm{C}-\mathrm{Y} x \mathrm{M}$, where $C$ stands for ceramic membrane, $x$ stands for the $\mathrm{Y}\left(\mathrm{NO}_{3}\right)_{3}$ impregnation solution molar concentration (M). The surfactant Pluronic P123 (BASF, Germany), which is a triblock copolymer comprising poly(ethylene oxide) and poly(propylene oxide), was added to improve the surface wetting and the filling of the pores during impregnation. Various impregnation repetitions and salt concentrations $(2.7 \mathrm{M}, 0.25 \mathrm{M}, 0.1 \mathrm{M}$ and $0.05 \mathrm{M})$ were tested to find the best conditions for producing a uniform thin protecting layer without clogging the membrane pores. The $\mathrm{Y}\left(\mathrm{NO}_{3}\right)_{3}$ concentration range was based on previous work on infiltration of porous ceramics and metal alloys. ${ }^{21,22}$ The $\mathrm{Y}\left(\mathrm{NO}_{3}\right)_{3}$ impregnation solution was dripped uniformly on the metal support surface and the excess solution was gently removed with a paper towel. The procedure was repeated up to three times. In case of 
multiple step of impregnation, after each step the samples were placed into a furnace at $350^{\circ} \mathrm{C}$ for 30 minutes and after the final impregnation step into a furnace at $350^{\circ} \mathrm{C}$ for 2 hours. A similar procedure with complete immersions of the membrane for 1 minute in a $2.7 \mathrm{M} \mathrm{Y}\left(\mathrm{NO}_{3}\right)_{3}$ solution was also attempted, but it led to severe clogging.

\section{Membrane characterization}

Microscopy and porosity

Scanning electron microscopy (SEM) and energy dispersive spectroscopy (EDS) were used to characterize the inorganic membrane microstructure and composition, to follow the effect of surface modification, and to verify the efficiency of the corrosion protection treatments. Microstructure of the sintered membranes including top view, bottom view, and polished cross-sections were investigated with SEM and EDS by using a microscope (Hitachi TM3000 tabletop SEM; Hitachi, Japan) and a higher resolution field-emission scanning electron microscope of the type Merlin FE-SEM (Carl Zeiss, Germany). The total porosity of different layers of the structure was determined from several SEM images using in-house developed software based on MATLAB. The open porosity and the pore-neck size distribution of the as-sintered membrane sample was characterized by mercury intrusion (Autopore IV 9500V1.05, Micromeritics Instrument Corporation, USA).

\section{Gas and water permeation}

Gas permeability was measured with an in-house built measurement set-up combined with a mass flow meter (Brooks, USA). The sample was prepared by gluing the membrane (diameter of $25 \mathrm{~mm}$ ) with the YSZ layer facing the sample holder. The exposed surface area $\left(A_{m}\right)$ of the membrane, which was not covered by adhesive, was precisely determined after the gas permeability measurements. The metal support side of the membrane was pressurized with pressures up to 5 bars and the YSZ layer side was connected to the mass flow meter. Different pressure gradients $(\Delta p)$ were applied across the membrane and measured with pressure gauges, and the corresponding gas flow $\left(Q_{v}\right)$ through the membrane was measured. The gas permeance $J_{\mathrm{g}}$ was calculated using Eq. 1

$$
J_{g}=\frac{Q_{V}}{\Delta p A_{m}}
$$

The water permeability tests were carried out in an Amicon $10 \mathrm{~mL}$ stirred ultrafiltration cell 8010 (Millipore, USA) as described below. Before being mounted in the cell, the membranes was initially washed in $50 \%$ ethanol. Water permeability was determined by measuring the flux of $10 \mathrm{~mL}$ MilliQ water across the membrane when applying a pressure of 0.2 bar above atmospheric pressure (barg). The water permeability, $L_{p}$, was calculated as:

$$
L_{p}=\frac{m_{w}}{\rho_{w} A_{m} t \Delta p}
$$

where $m_{w}$ is the measured weight of water permeate, $\rho_{w}$ is the density of water, and $t$ is the filtration time. 
Surface wettability and stability

In order to observe possible variations in wettability as effect of different surface treatments of the membranes, qualitative observations of the contact angle were performed. The sample of as-sintered membrane was compared with homologues after heat treatment (C-HT800), and after $\mathrm{Y}$ impregnation ( $\mathrm{C}-\mathrm{Y} 2.7 \mathrm{M})$. For this experiment, drops of $0.1 \mathrm{M}$ Tris- $\mathrm{HCl}$ buffer $(\mathrm{pH} 7)$ were added on the metal support side. The drop shape was recorded with pictures just after deposition (Figure $\mathrm{S} 2$ ).

Three types of membranes (as-sintered, C-HT800, and C-Y0.25M) were submerged in $0.1 \mathrm{M}$ Tris-HCl buffer with $330 \mathrm{mg} \mathrm{Cl} / \mathrm{L}$ for 1 year at room temperature to study the microstructural stability of the membranes in an environment commonly used for enzymatic reactions.

\section{Experimental setup for enzyme immobilization and reactions}

All experiments were carried out as dead-end batch filtrations in an Amicon 8010 stirred cell (Millipore, USA) following the same procedures for water permeability measurements, enzyme immobilization, protein concentration measurement, and activity assay as described previously. ${ }^{23}$ The working volume of the stirred cell was $10 \mathrm{~mL}$, and it was equipped with a membrane which was $25 \mathrm{~mm}$ in diameter and had an active membrane area of $4.1 \mathrm{~cm}^{2}$. Constant pressure across the membrane was applied by feeding nitrogen gas to the cell. All filtrations took place at $22 \pm 1^{\circ} \mathrm{C}$.

\section{Enzyme immobilization}

\section{Enzyme and chemicals}

Lyophilized powder of alcohol dehydrogenase (ADH; EC 1.1.1.1; $\geq 90 \%)$ from Saccharomyces cerevisiae, formaldehyde ( $37 \% \mathrm{CH}_{2} \mathrm{O}$ in $\mathrm{H}_{2} \mathrm{O}$ ), $\beta$-nicotinamide adenine dinucleotide reduced disodium salt hydrate (NADH, $\geq 97 \%$ ), (3-aminopropyl)triethoxysilane (APTES, 99\%), polyethylenimine ( $\mathrm{PEI}, 50 \%$ in $\mathrm{H}_{2} \mathrm{O}$, average molecular weight $60 \mathrm{kDa}$ ), bovine serum albumin (BSA, $\geq 98 \%$ ), Bradford reagent, and all other chemicals were obtained from Sigma-Aldrich (Steinheim, Germany). $10 \%$ glutaraldehyde (GA) in $\mathrm{H}_{2} \mathrm{O}$ was supplied by Novozymes $A / S$ (Bagsværd, Denmark).

\section{Enzyme immobilization}

The ADH immobilization was done from the YSZ layer side of the membranes (Figure 1). For immobilization by physical adsorption, a solution of $20 \mathrm{mg} \mathrm{ADH} / \mathrm{L}$ was prepared in $0.1 \mathrm{M}$ Tris- $\mathrm{HCl}$ buffer ( $\mathrm{pH} 7.0$ ), and $10 \mathrm{~mL}$ of this solution was filtered through the membrane in an Amicon $10 \mathrm{~mL}$ stirred ultrafiltration cell 8010 (Millipore, USA) without applied pressure. Afterwards, the membrane was washed by filtering $10 \mathrm{~mL}$ of $0.1 \mathrm{M} \mathrm{Tris}-\mathrm{HCl}$ buffer ( $\mathrm{pH}$ 7.0) through at an applied pressure of 0.2 barg. Samples of the feed, the permeate, any remaining retentate, and the wash were kept for determining enzyme loading.

APTES functionalization was carried out by submersion of the membranes in $10 \mathrm{~mL}$ of $2 \%(\mathrm{v} / \mathrm{v}$ ) APTES at $70^{\circ} \mathrm{C}$ for $90 \mathrm{~min}$ followed by dead-end filtration of the hot APTES through the membrane in the stirred cell 
without applying pressure. The procedure was based on an optimization study on APTES grafting on magnetic iron oxide nanoparticles. ${ }^{24}$ Excess APTES was washed away with $50 \mathrm{~mL}$ of Milli-Q water at 0.2 barg. For activation, $10 \mathrm{~mL}$ of $2.5 \%(\mathrm{v} / \mathrm{v}) \mathrm{GA}$ was filtered through the membrane without applied pressure followed by a rinse with 50 $\mathrm{mL}$ of Milli-Q water at 0.2 barg. This concentration of GA is commonly used for protein immobilization using functionalization with APTES or PEI (below). ${ }^{25-27}$ Enzyme immobilization was completed as described for physical adsorption. This method is denoted the APTES-GA method.

PEI functionalization was carried out by filtration of $10 \mathrm{~mL} 0.1 \%(\mathrm{v} / \mathrm{v})$ PEI solution with no applied pressure; PEI concentrations in this range are commonly used for enzyme immobilization. ${ }^{25,26}$ Excess PEI was removed by filtration of $50 \mathrm{~mL}$ of Milli-Q water at 0.2 barg. Activation with GA, enzyme immobilization, and the subsequent wash were carried out as described for APTES-GA above. This method is denoted the PEI-GA method.

\section{Enzyme loading determination}

Protein concentration in the feed solution, permeate, and wash solutions was determined by mixing the samples 1:1 with Bradford reagent. Samples were mixed and the absorbance was measured at $595 \mathrm{~nm}$ after 5 minutes of incubation at room temperature. External standards of bovine serum albumin (BSA) in $100 \mathrm{mM} \mathrm{Tris-HCl}$ buffer $(\mathrm{pH}$ 7.0) were used for protein quantification. Amount of immobilized enzyme and enzyme loading yield (ELY), i.e. the percentage of the enzyme in the feed solution which was immobilized on the metal-supported YSZ membrane, were determined from a mass balance as described previously. ${ }^{28}$

\section{Immobilized enzyme activity}

The activity of free or immobilized $\mathrm{ADH}$ was measured using a substrate solution containing $30 \mathrm{mM}$ formaldehyde $\left(\mathrm{CH}_{2} \mathrm{O}\right)$ and $100 \mu \mathrm{M} \mathrm{NADH}$ in $100 \mathrm{mM}$ Tris- $\mathrm{HCl}$ buffer $\left(\mathrm{pH} \mathrm{7.0)}\right.$ at $22 \pm 1^{\circ} \mathrm{C}$. The reduction of formaldehyde to methanol takes place with concomitant, stoichiometric oxidation of NADH to NAD'. The nicotinamide moiety has a specific absorbance maximum at $340 \mathrm{~nm}$, but only when protonated. Thus, ADH activity was measured as NADH conversion at $340 \mathrm{~nm}$ using a molar extinction coefficient for NADH of $6220 \mathrm{M}^{-1}$ $\mathrm{cm}^{-1}$. However, since NADH also spontaneously decomposes, ${ }^{29}$ great care was taken to include appropriate control measurements, e.g. measurement of the NADH concentration in the feed solution immediately prior to placing it in the stirred cell. The NADH solution was freshly prepared every day. For immobilized ADH, $10 \mathrm{~mL}$ of substrate solution was placed in the stirred cell with the YSZ layer on the feed side and metal support on the permeate site (Figure 1). A pressure of 0.2 barg was applied and permeate collection was started immediately. The filtration time was recorded and the $\mathrm{NADH}$ concentration in the permeate was determined by spectrophotometry. When enzyme recycling studies were performed, the assay was continued with additional $10 \mathrm{~mL}$ of reactant solution for several cycles. The NADH conversion (\%) catalyzed by immobilized ADH, $X_{i m m}$, was calculated from the concentration in the feed solution $\left(c_{f}\right)$ and permeate $\left(c_{p}\right)$ as described previously: $:^{28}$

$$
X_{i m m}=\frac{c_{f}-c_{p}}{c_{f}} \cdot 100 \% \quad \text { (Eq.3) }
$$


The immobilized enzyme activity was compared to that of free ADH at enzyme concentrations of 0-14 $\mathrm{mg} / \mathrm{L}$. ADH, $30 \mathrm{mM}$ formaldehyde, and $100 \mu \mathrm{M}$ NADH were dissolved in $100 \mathrm{mM}$ Tris-HCl buffer (pH 7.0) just prior to the reaction in 96-well UV microplates and the absorbance at $340 \mathrm{~nm}$ was measured every $11 \mathrm{~s}$ for 10 min in a Tecan Infinite ${ }^{\circledR}$ M200 plate reader (Tecan Trading AG, Switzerland). From this, the activity of free ADH, $X_{\text {free, }}$ was estimated from a 3D plot of free ADH activity at 0-14 $\mathrm{mg} \mathrm{ADH/L}$ and 0-609 s reaction time, at the enzyme dosage and reaction time corresponding to those of the immobilized enzyme (Figure 6). To compare the activity of immobilized $A D H, X_{\text {imm }}$, to that of the free enzyme, $X_{\text {free, }}$ the residual activity $\eta(\%)$ was calculated:

$$
\eta=\frac{X_{\text {imm }}}{X_{\text {free }}} \cdot 100 \% \quad \text { (Eq.4) }
$$

As a negative control, the effect of the metal-supported ceramic membrane material on the NADH degradation was investigated. Each type of membrane (as-sintered membranes, C-Y0.05M, and C-Y0.10M) without immobilized enzyme was incubated in the substrate solution (30 mM formaldehyde and $100 \mu \mathrm{MADH}$ in $0.1 \mathrm{M}$ Tris- $\mathrm{HCl}$ buffer, $\mathrm{pH} \mathrm{7.0)}$ ) and monitored for $50 \mathrm{~min}$ (a time span corresponding to the 15 reaction cycles in the recycling study of the physically adsorbed enzyme).

\section{Re-burning for membrane reuse}

The YSZ membranes - both heat-treated and $\mathrm{Y}_{2} \mathrm{O}_{3}$-coated - were heat-treated at $350^{\circ} \mathrm{C}$ after $\mathrm{ADH}$ immobilizations by physical adsorption, APTES-GA and PEI-GA and the subsequent reactions in order to explore the potential of this method for membrane reuse. The membranes were heat-treated at $350^{\circ} \mathrm{C}$ in air in four different stages, giving a total heating time of 6-11 hours (Table 1). After each re-burn stage, the water permeability of the membranes was measured. As a part of the exploratory study, a set of membranes was selected to investigate the reusability of them for enzyme immobilization. The same method of immobilization as prior to the re-burning was used, and the ADH activity and enzyme loading yield were determined.

\section{Statistics}

One-way ANOVA for determination of statistical significance was performed with JMP ${ }^{\circledR}$, version 13 (SAS Institute Inc., USA). Statistical significance was established at $p<0.05$.

\section{Results and discussion}

\section{Membranes architecture}

To ensure processing procedures that are cost-efficient, scalable, and with minimum number of processing steps, tape casting was chosen as a processing technique for the bilayer structure preparation. In order to prove robustness and upscaling possibilities, the bilayer membranes were co-sintered in large pieces in a single step (Figure 2). The metal-ceramic membranes with an membrane surface area of $120 \times 120 \mathrm{~mm}^{2}$ (Figure 2) were successfully fabricated by combining layers with compatible shrinkage. The metal support layer with a thickness of $290 \mu \mathrm{m}$ had porosity of $21 \pm 2 \%$ and the thin YSZ ceramic layer with a thickness $7 \pm 1 \mu \mathrm{m}$ had porosity of $44 \pm$ $5 \%$. The layer porosity and thickness demonstrated a good reproducibility in the layer production with respect 
to both parameters as demonstrated by SEM images (Figure S1). The porosity distribution measured by mercury intrusion porosimetry showed Gaussian distribution with average bottlenecks of $10 \pm 1 \mu \mathrm{m}$ in the metal support and $0.41 \pm 0.08 \mu \mathrm{m}$ in the YSZ layer, and is in good agreement with the membrane microstructure (Figure S1). The water permeability of the metal-ceramic membranes was $12000 \pm 1300 \mathrm{~L} /\left(\mathrm{m}^{2} \mathrm{~h}\right.$ bar). Similar work has been reported by Lin et al., ${ }^{30}$ where the $\mathrm{TiO}_{2}$ membrane layer with a pore size of $380 \mathrm{~nm}$ was directly sprayed on the Ti support with a pore size of $13 \mu \mathrm{m}$. In that case, a water permeability of $1150 \mathrm{~L} /\left(\mathrm{m}^{2} \mathrm{~h}\right.$ bar) was measured. In most other cases where metal or alloy supports have been used, the microfiltration membranes consist of several layers with a gradual decrease in pore size towards the feed side of the membrane. ${ }^{8,9}$

\section{Surface modifications of membranes}

Two different surface treatments were applied to the metal-supported membranes with the dual purpose of studying their effect on the enzyme immobilization and activity and testing their efficiency in corrosion protection in Tris/ $\mathrm{HCl}$ buffer solution: 1) Yttrium nitrate $\left(\mathrm{Y}\left(\mathrm{NO}_{3}\right)_{3}\right)$ impregnation for the formation of an $\mathrm{Y}_{2} \mathrm{O}_{3}$ layer after calcination; 2) Heat treatment for the formation of $\mathrm{Cr}_{2} \mathrm{O}_{3}$ protective scales. Both treatments can potentially improve the enzyme immobilization if the proteins have special affinity for $\mathrm{Cr}_{2} \mathrm{O}_{3}$ or $\mathrm{Y}_{2} \mathrm{O}_{3}$.

\section{$\mathrm{Y}\left(\mathrm{NO}_{3}\right)_{3}$ impregnation}

Impregnation experiments performed with different numbers of impregnation steps and varying $\mathrm{Y}\left(\mathrm{NO}_{3}\right)_{3}$ concentrations were necessary for finding the ideal conditions for preparing a $\mathrm{Y}_{2} \mathrm{O}_{3}$ protective coating thin enough to preserve the good water permeability achieved with the as-sintered membranes. The preserved open porosity of the membranes and quantitative discrimination between different procedures were evaluated by gas permeability measurements as a means of screening the samples before water permeability measurements and enzyme immobilization. These tests highlighted the strong influence of the impregnation solution concentration. The gas permeance increased linearly with the pressure gradient for the as-sintered membranes, the heattreated membranes and the impregnated membranes with low concentration of $\mathrm{Y}\left(\mathrm{NO}_{3}\right)_{3}$ solutions $(\leq 0.25 \mathrm{M}$; Figure 3). In contrast, for the membranes impregnated with the high concentration of $\mathrm{Y}\left(\mathrm{NO}_{3}\right)_{3}$ solution $(2.7 \mathrm{M})$, the gas permeation was much lower and it was almost independent on the pressure gradient. In general, the gas permeance depends on the membrane thickness, open porosity and pore size distribution. The $\mathrm{Y}_{2} \mathrm{O}_{3}$ coating lies mainly in the membrane pores modifying the porosity and/or the pore size distribution, but does not alter the layers' thickness, as visible in the SEM images (Figure 4). Therefore, the observed reduction of the gas permeance as a function of $\mathrm{Y}\left(\mathrm{NO}_{3}\right)_{3}$ concentration and repeated impregnation steps $(1 \mathrm{x}, 2 \mathrm{x}, 3 \mathrm{x})$ is due to larger amount of $\mathrm{Y}_{2} \mathrm{O}_{3}$ coating in the membrane.

The water permeability measurements confirmed the membrane clogging at high $\mathrm{Y}\left(\mathrm{NO}_{3}\right)_{3}$ concentration, where the water permeation was $0 \mathrm{~L} /\left(\mathrm{m}^{2} \mathrm{~h}\right.$ bar) for the $\mathrm{C}-\mathrm{Y} 2.7 \mathrm{M}$ membrane and $7800 \mathrm{~L} /\left(\mathrm{m}^{2} \mathrm{~h}\right.$ bar) for the CY0.25M. For the membranes impregnated with the low $\mathrm{Y}\left(\mathrm{NO}_{3}\right)_{3}$ concentrations (C-Y0.10M and C-Y0.05M) the water permeation was in the same range of the non-impregnated membrane (as-sintered) around $13000 \mathrm{~L} /\left(\mathrm{m}^{2} \mathrm{~h}\right.$ 
bar) (Table 3). Therefore, the surface modification and anti-corrosion treatment via $Y$ impregnation suitable for enzyme immobilization was defined with one impregnation cycle and $\mathrm{Y}\left(\mathrm{NO}_{3}\right)_{3}$ concentration $\leq 0.25 \mathrm{M}$.

High resolution SEM and chemical mapping obtained by EDS analyses were performed on the membrane cross section (as-sintered) after a single impregnation cycle with two different salt concentrations, $0.25 \mathrm{M}$ and 2.7M Y (Figure 4). As $Y$ is a structural element in the YSZ layer, the EDS analysis could only highlight differences in the metal support. The visualized $\mathrm{Y}_{2} \mathrm{O}_{3}$ distribution in the metal-ceramic membrane was $\mathrm{Y}\left(\mathrm{NO}_{3}\right)_{3}$ concentration dependent. In fact, the decreased salt concentration in the $\mathrm{Y}\left(\mathrm{NO}_{3}\right)_{3}$ impregnation solution reduced the $\mathrm{Y}$ content in the metal support pores and its distribution became more homogeneous (Figure 4a-b).

The high-resolution SEM images display the $Y$ distribution both in the metal support (Figure $4 \mathrm{c}-\mathrm{d}$ ) and in the YSZ layer (Figure 4e-f). The arrows point at $\mathrm{Y}_{2} \mathrm{O}_{3}$ bridges reducing the pore size in the metal support. $\mathrm{Y}_{2} \mathrm{O}_{3}$ was also visibly located in the high curvature porosity (for example, $\mathrm{Y}$ is represented in light blue in the insert of Figure $4 d)$. The amount of $Y$ on the rest of the metal support surface was at the limit of EDS sensitivity. In the YSZ layer, segregated $\mathrm{Y}_{2} \mathrm{O}_{3}$ was clearly observed in the SEM images as darker nano-sized inserts within the pores for the high $\mathrm{Y}\left(\mathrm{NO}_{3}\right)_{3}$ concentration $(2.7 \mathrm{M}$; arrows, Figure $4 \mathrm{e})$. On the other hand, the medium $\mathrm{Y}\left(\mathrm{NO}_{3}\right)_{3}$ concentration $(0.25 \mathrm{M})$ showed no $\mathrm{Y}_{2} \mathrm{O}_{3}$ segregation in the pores of the $\mathrm{YSZ}$ layer (Figure 4f). Both $\mathrm{Y}_{2} \mathrm{O}_{3}$ segregation and $\mathrm{Y}_{2} \mathrm{O}_{3}-$ bridges can explain the observed membrane clogging measured by gas and water permeation at high $\mathrm{Y}\left(\mathrm{NO}_{3}\right)_{3}$ concentration. For the $0.25 \mathrm{M} \mathrm{Y}\left(\mathrm{NO}_{3}\right)_{3}$ impregnation solution, the reduced permeation can be clearly connected to the observed $\mathrm{Y}_{2} \mathrm{O}_{3}$-bridges in the metal support. However, the absence of $\mathrm{Y}_{2} \mathrm{O}_{3}$ segregation in the YSZ layer results in unaltered permeation through this layer. Most likely, $\mathrm{Y}_{2} \mathrm{O}_{3}$ segregation and $\mathrm{Y}_{2} \mathrm{O}_{3}$-bridges is even further reduced at low $\mathrm{Y}\left(\mathrm{NO}_{3}\right)_{3}$ concentration $(0.05-0.1 \mathrm{M})$ as supported by the increased gas permeance and water permeability (Figure 3; Table 3).

The other effect of $\mathrm{Y}_{2} \mathrm{O}_{3}$ impregnation is the pore surface modification in the metal support and in the YSZ layer. In the latter, the formation of small nano-sized yttria particles can increase the surface area of the YSZ layer, and therefore the number of available sites for the adsorption of enzymes.

\section{Heat treatment of membranes}

The curves of gas permeance before and after heat treatments follow each other very closely, showing that heat treatment at $800^{\circ} \mathrm{C}$ does not affect the porosity and pore size in the metal support and in the YSZ layer (Figure 3). On the other hand, the water permeability increased after the heat treatment to $15300 \mathrm{~L} /\left(\mathrm{m}^{2} \mathrm{~h}\right.$ bar) (Table 3). This finding indicates that small changes in the microstructure occurred. At the same time, hydrophilicity of the metal is increased, as supported by qualitative contact angle observations performed on the metal side before and after surface treatments (Figure S2).

The high temperature heat treatment induced the formation of a protecting $\mathrm{Cr}_{2} \mathrm{O}_{3}$-rich thin layer on the pore surface in the metal support, visible as a darker layer indicated with arrows in Figure 5 . The thickness of the layer is around $100 \mathrm{~nm}$ and it is homogeneous across the entire surface, i.e. at the interface between metal support and the YSZ layer (Figure 5a) as well as at the pore surface of the metal support (Figure 5c). For all 
samples, the EDS analysis was repeated several times on three different sites of the metal support: In the bulk, on the pore surface, and on the fractured oxide layer (Figure $5 \mathrm{c}$ insert). In the original as-sintered sample, the amount of $\mathrm{Cr}$ was the same in all three different sites (Table 2), showing a uniform alloy composition. After heat treatment the formation of the $\mathrm{Cr}_{2} \mathrm{O}_{3}$-rich layer was proven by an increased amount of $\mathrm{Cr}$ in the pore surface layer (60\%) compared to the bulk (22\%) (Table 2).

\section{Membrane stability in Tris-HCl buffer}

As a corrosion test, the membranes were exposed for 1 year to a Tris- $\mathrm{HCl}$ buffer solution (pH 7) with $330 \mathrm{mg} \mathrm{Cl}^{-}$ L, which is commonly used for enzymatic reactions. After 1 year of submersion, the SEM micrographs collected on the membranes did not indicate any significant change in the tested samples (Figure 5a-b). In addition, the thickness of the $\mathrm{Cr}_{2} \mathrm{O}_{3}$-rich layer on the pore surface of the metal support of the heat-treated sample (C-HT800) remained the same as before the exposure (Figure $5 a-b)$. In general, the corresponding EDS analysis showed no significant difference between the original samples and the 1-year exposed samples (Table 2). The Fe/Cr ratios of most of the samples were the same before and after buffer exposure corresponding to the $22 \%$ of $\mathrm{Cr}$ in steel. This agrees well with reported passivation properties of the high $\mathrm{Cr}$ content steels. ${ }^{31}$ Lack of the reports about enzymatic reactors with immobilized enzymes on metal supports disables the direct comparison of their stability. However, for long-term operation the corrosion cannot be completely excluded, as it was recently reported that a slightly different steel with high $\mathrm{Cr}$ content (18\%) did not withstand the corrosion after 12 years of servicing in a reclaimed water plant with a similar chlorine concentration as used here $(261 \mathrm{mg} / \mathrm{L}) .{ }^{11}$

\section{Enzyme immobilization by physical adsorption}

As a first means of comparison between the membrane surface treatments, ADH was immobilized by simple physical adsorption. The reduction in water permeability after enzyme immobilization was identical for the assintered and $\mathrm{Y}_{2} \mathrm{O}_{3}$-coated membranes (52-58\%), whereas it was lower for the heat-treated ones (36\%; Table 3).

Due to large standard deviations, no statistically significant differences were observed between the enzyme loadings obtained in the different membranes (Table 3). Nevertheless, some general tendencies were ohserved: The lowest enzyme loading yield (ELY; 17\%) was observed for the membranes C-Y0.25M (Table 3). This may be explained by the $\mathrm{Y}_{2} \mathrm{O}_{3}$ coating blocking some of the pores, thus decreasing the membrane porosity and making the available immobilization area smaller (Figure 3). In contrast, the membranes C-Y0.1M showed the highest ELY (33\%) indicating that moderate amount of the $\mathrm{Y}_{2} \mathrm{O}_{3}$ coating is beneficial for ADH immobilization by physical adsorption (Table 3). In turn, the membranes C-Y0.05M showed an ELY (29\%) comparable to that of the untreated membrane (as-sintered; $28 \%$ ), whereas the immobilization efficiency was slightly lower (23\%) for the heat-treated membrane (Table 3). These loading yields were slightly lower but still comparable to those reported for a laccase immobilized by physical adsorption onto titania and silica nanoparticles (53\% and 33\%, respectively). ${ }^{32}$ 
As the reaction time of the enzymatic reaction is defined as the time it takes for $10 \mathrm{~mL}$ substrate solution to pass through the membrane, this parameter is strongly linked to the water permeability of the samples investigated. In the case of the membranes C-Y0.25M, the reaction time was approx. 3 times longer than the other samples, giving rise to higher NADH conversion, since the reaction yield is indeed time dependent (Table 3).

The residual activity $\eta$ of the immobilized ADH was calculated by Eq. 4 taking into account the NADH conversion measured for each type of membrane and the corresponding NADH conversion of the free enzyme $\left(X_{\text {free }}\right)$. The corresponding $X_{\text {free }}$ was estimated at the same enzyme concentration as in the membranes and the same reaction time (Figure 6 , left). In all cases, the activity of the immobilized enzyme was lower than that of the free enzyme as is often observed in enzyme immobilization - also for $A D H .{ }^{18,33}$ The residual activity was similar for as-sintered, heat-treated (C-HT800), C-Y0.10M and C-Y0.05M membranes, but significantly higher for the CY0.25M membranes (Table 3).

In conclusion, the heat treatment increased the water permeability of the membrane, but did not improve its performance as immobilization support. On the other hand, $\mathrm{Y}_{2} \mathrm{O}_{3}$-coating did improve the immobilization performance, but $\mathrm{Y}\left(\mathrm{NO}_{3}\right)_{3}$ concentration was an important factor. Indeed, while C-Y0.25M gave the highest NADH conversion and residual activity due to a higher reaction time caused by decreased water permeability, its ELY was lower than that obtained with C-Y0.10M (Table 3). Thus, the right $\mathrm{Y}\left(\mathrm{NO}_{3}\right)_{3}$ concentration will depend on the desired parameter to be optimized. The increased amount of immobilized enzyme at CY0.10M compared to as-sintered membrane and C-HT800 can be due to differences in the surface charge, besides the increased surface area due to formation of $\mathrm{Y}_{2} \mathrm{O}_{3}$ nanoparticles. The as-sintered membrane is expected to have a relatively pure metal surface due to preparation method. The heat treatment (C-HT800) oxidizes the metal surface and forms a $\mathrm{Cr}_{2} \mathrm{O}_{3}$ scale. The oxidation decreases the isoelectric point (IEP) as was observed for stainless steel heat-treated at $1000^{\circ} \mathrm{C}$ in air, where the IEP was reduced from 4.2 to $2.8 .^{34}$ In C$\mathrm{Y} 0.10 \mathrm{M}$, the $\mathrm{Y}_{2} \mathrm{O}_{3}$-coating formed on both the $\mathrm{YSZ}$ layer and the metal support is expected to have the opposite effect and will increase the IEP. As reported by Kagawa et al. ${ }^{35}$ the IEP of YSZ was 6.5, whereas the IEP of $\mathrm{Y}_{2} \mathrm{O}_{3}$ is $8.8 .{ }^{35}$ Therefore, at $\mathrm{pH} 7$ the zeta potential of the $\mathrm{Y}_{2} \mathrm{O}_{3}$-coating will be positive, whereas that of $\mathrm{YSZ}$ will be slightly negative and that of the metal and the heat-treated metal will be negative. Since the highest amount of immobilized enzyme was measured on C-Y0.10M and the IEP of ADH is 5.4-5.8 (product information, Sigma Aldrich) it can be speculated that the enzyme prefers a positively charged surface under the conditions studied here.

ADH immobilized on the membranes C-Y0.05M, C-Y0.1M, and on the as-sintered membrane was tested for activity over 15 consecutive reaction cycles (Figure 7). The ADH activity decreased during the first few cycles but even after 7 cycles the enzyme was stable with residual activity of 6\%. From cycle 7 to cycle 15 the activity level remained fairly constant for the as-sintered and C-Y0.10M, whereas it kept decreasing for the C-Y0.05M (Figure 7). After the $15^{\text {th }}$ cycle the enzyme was still active with the residual activity of $4-5 \%$ for all tested samples. Since the ADH activity was measured by NADH conversion, the NADH stability in a blank sample was evaluated. NADH 
exhibited a slight, linear degradation over time when present in the substrate solution without ADH, which was accounted for in all experiments. The degree of this NADH decay in the absence of ADH was unaffected by the presence of the metal-supported ceramic membranes regardless of their surface coating, the coefficient of variation between the decay slopes being below 4\% (Figure S3). Thus, the maintained conversion was not catalyzed by the membrane material, but rather by ADH. A decrease in immobilized ADH activity over time is to be expected, but often less dramatic than observed here. ${ }^{17,18}$ It was recently discovered that the use of Tris- $\mathrm{HCl}$ buffer in the ADH-formaldehyde system has a detrimental effect on ADH activity. ${ }^{29}$ Thus, it is likely that the low activity obtained here during recycling - as well as the results obtained in previous works on which the operating conditions were based - could be improved by exchanging the buffer in future work. While the results can stem from a combination of enzyme leakage and inactivation, they emphasize the need of a more robust immobilization solution. Indeed, silanization of YSZ and stainless steel surfaces to create anchor points for covalent immobilization of enzymes is commonly used. ${ }^{36-39}$ Less leaching from the YSZ support was found for covalently immobilized lysozyme as compared to lysozyme immobilized by simple adsorption. ${ }^{36}$ Consequently, membranes subjected to either kind of surface treatment - heat treatment (C-HT800) and impregnation with $0.25 \mathrm{M} \mathrm{Y}\left(\mathrm{NO}_{3}\right)_{3}$ - were selected for covalent immobilization studies.

\section{Covalent enzyme immobilization}

Only few studies report the use of YSZ as a support for enzyme immobilization. ${ }^{36-38,40}$ Often, acidic or hydrothermal hydroxylation is employed to generate more hydroxyl groups on the surface for silanization with APTES or other organosilanes. ${ }^{36,37,40}$ Subsequently, activation with e.g. $N$-hydroxysuccinimide (NHS) or 1-ethyl-3(3-dimethylaminopropyl)carbodiimid (EDC) is followed by covalent enzyme attachment. ${ }^{36,38,40}$ Since the majority of the material in these metal-supported ceramic membranes is in fact the stainless steel support, it is likely that $\mathrm{ADH}$ will also be immobilized in the support layer. In literature, reports on enzyme immobilization on stainless steel include successful covalent immobilization by APTES functionalization or by coating of the stainless steel support with PEI. ${ }^{39,41}$ However, efficient functionalization of stainless steel with APTES or PEI also often requires introduction of hydroxyl groups on its surface, e.g. by etching or by coating with a titania-based material. ${ }^{39,41,42}$ Both support functionalization methods were investigated in the current work and compared to the simplest enzyme immobilization method, physical adsorption (Table 4).

As established above, the initial water permeability of the C-Y0.25M membranes was $57 \%$ of the water permeability of the heat-treated membranes, indicating that the $\mathrm{Y}_{2} \mathrm{O}_{3}$-coating reduced the open porosity and pore-neck size resulting in a lower water flux (Table 4). In addition, the reduction in water permeability upon immobilization was significantly more pronounced for the $\mathrm{Y}_{2} \mathrm{O}_{3}$-coated membranes than for the heat-treated ones, irrespective of the immobilization method (Table 4). The different immobilization methods also affected the water permeability differently. For both membrane types, physical adsorption had the least impact on water permeability, resulting in a reduction of $36 \%$ and $58 \%$, respectively, for the heat-treated and the $\mathrm{Y}_{2} \mathrm{O}_{3}$-coated membranes, which was significantly less than obtained with the covalent immobilization methods (Table 4). 
Indeed, APTES-GA caused water permeability reduction of $62 \%$ for the heat-treated membranes and $87 \%$ for the $\mathrm{Y}_{2} \mathrm{O}_{3}$-coated ones. Coating with PEI followed by GA activation and ADH immobilization resulted in water permeability decreases of $72 \%$ for the heat-treated membranes and as much as $94 \%$ for the $\mathrm{Y}_{2} \mathrm{O}_{3}$-coated one (Table 4). A water permeability reduction of $94 \%$ had severe consequences for the flux across the membrane. Therefore, the effect of PEI concentration in the solution used for functionalization of the $\mathrm{Y}_{2} \mathrm{O}_{3}$-coated membranes was tested by using 10-times and 100-times lower concentrations of PEI. A 10 times lower PEI concentration of $0.01 \%(\mathrm{w} / \mathrm{v})$ resulted in a water permeability reduction of $86 \%$, which was comparable to that obtained with APTES-GA, and a water flux which was almost doubled as evidenced by the reaction time which is equal to the filtration time (Table 4). The enzyme loading at $0.01 \%(\mathrm{w} / \mathrm{v})$ PEI was the same as obtained with $0.1 \%$ $(\mathrm{w} / \mathrm{v})$ PEI (Table 4). Decreasing the PEI concentration for another 10 times to $0.001 \%(\mathrm{w} / \mathrm{v})$ did not have any significant effect on water permeability, enzyme loading or activity compared to the $0.01 \%(\mathrm{w} / \mathrm{v})$ PEI solution (Table 4). This indicates that all the investigated concentrations of PEI are sufficient to coat the entire membrane. The data emphasize that the thickness of the PEI layer should be fine-tuned in order to maintain the highest possible water permeability without compromising immobilization efficiency or enzyme activity.

The amount of immobilized enzyme and the corresponding enzyme loading yield was more dependent on the immobilization method than on the membrane type. For physical adsorption and PEI-GA, no significant difference was found between the membrane types, whereas there was a dramatic influence of applying a covalent immobilization method: the enzyme loading yield was $17-23 \%$ for physical adsorption and $53-58 \%$ for PEI-GA (Table 4). For APTES-GA, which also showed a significantly higher immobilization efficiency than physical adsorption, the enzyme loading yield of $49 \%$ for the heat-treated membranes was significantly higher than that of $38 \%$ observed for the $\mathrm{Y}_{2} \mathrm{O}_{3}$-coated ones (Table 4). APTES grafting is particularly dependent on the presence of hydroxyl groups on the surface. It can be speculated that the thin $\mathrm{Cr}_{2} \mathrm{O}_{3}$-rich layer formed on the stainless steel surface during the heat treatment at $800^{\circ} \mathrm{C}$ can provide more hydroxyl groups than the inhomogeneous $\mathrm{Y}_{2} \mathrm{O}_{3}$ coating on the metal support, which was found to also form $\mathrm{Y}_{2} \mathrm{O}_{3}$-bridges blocking part of the pores in the structure (Figure 4d).

As mentioned, the reduction in water permeability observed for the $\mathrm{Y}_{2} \mathrm{O}_{3}$-coated membranes narticularly for the ones subjected to the two covalent immobilization methods - had a direct influence on the reaction time, since this was identical to the filtration time. The reaction time in the heat-treated membrane was much shorter than in the $\mathrm{Y}_{2} \mathrm{O}_{3}$-coated membranes. In turn, significantly higher NADH conversions were observed for the $\mathrm{Y}_{2} \mathrm{O}_{3}$-coated membranes when comparing to the heat-treated membranes. Besides, for the $\mathrm{Y}_{2} \mathrm{O}_{3}$-coated membranes the reaction time, and consequently the NADH conversion, was higher for the covalently immobilized $A D H$ when comparing to those with $A D H$ immobilized by physical adsorption (Table 4). For ADH immobilized by APTES-GA or PEI-GA on the $\mathrm{Y}_{2} \mathrm{O}_{3}$-coated membranes, $\mathrm{NADH}$ conversions of $90 \%$ and $98 \%$, respectively, were observed. The differences in NADH conversion were not significant between the two covalent immobilization methods (Table 4). In contrast, the NADH conversion was only $41 \%$ for the physically adsorbed $\mathrm{ADH}$. For the heat-treated membranes, NADH conversions of $13 \%, 37 \%$, and $44 \%$, respectively, were observed 
for physical adsorption, APTES-GA, and PEI-GA. Using the same immobilization techniques on ceramic silicon carbide membranes, it was previously shown that reaction time and water permeability were inversely proportional. ${ }^{23}$ This implies that the effect of water permeability on reaction time is particularly pronounced at low water permeability values such as the ones observed in the $\mathrm{Y}_{2} \mathrm{O}_{3}$-coated membranes with covalently immobilized ADH.

The residual activity $\eta$ relates the observed immobilized activity to that of the free enzyme at the corresponding enzyme dosage and reaction time (Figure 6, right). Thus, apart from comparing free and immobilized $A D H$ this is also a means of taking into account both the enzyme loading and the reaction time (caused by the resulting water permeability). For APTES-GA and PEI-GA the reaction times in the $\mathrm{Y}_{2} \mathrm{O}_{3}$-coated membranes were so long, that the reaction had plenty of time to run to reactant depletion and the resulting residual activities were high and similar to each other despite significant differences in the enzyme loading (Figure 6, right; Table 4). This makes it hard to distinguish the effect of the surface modification from the effect of reaction time. However, it is evident that the two covalent immobilization methods had a positive effect on the residual activity (Table 4; Figure 6, right). Significantly higher enzyme loadings, substrate conversion, and in turn residual activity were obtained with APTES-GA and PEI-GA compared to physical adsorption: the enzyme loading was doubled with the covalent methods, while the substrate conversion was tripled (Table 4). In terms of substrate conversion and residual activity, there were no significant differences between the two covalent methods (Table 4).

Several studies report higher immobilization efficiency when using one of these covalent methods on stainless steel, YSZ, or other ceramic materials as compared to physical adsorption. Grafting APTES to etched stainless steel and in turn immobilizing lysozyme by GA cross-linking resulted in a 4-fold higher activity compared to physical adsorption. ${ }^{39}$ Similarly, a 4 times higher loading of $\beta$-fructofuranosidase was obtained through silanization with the very similar organosilane (3-aminopropyl)trimethoxysilane (APTMS) and GA activation on acid-treated ceramic membranes of an undisclosed material. ${ }^{43}$ APTES-GA immobilization of laccase on titania particles resulted in a 1-6 times higher enzyme loading than obtained with physical adsorption. ${ }^{32}$ APTES grafting of YSZ microtubes followed by activation with EDC to immobilize lysozyme resulted in an enzyme loading which was approx. 6 times higher than that obtained with physical adsorption. In turn, this resulted in activities which were approx. 2 times higher. However, the specific activity was approx. 4 times lower for the covalently immobilized enzyme, indicating that the covalent immobilization may distort the three-dimensional structure of the enzyme, cause steric hindrances, or in other ways reduce its activity. ${ }^{36}$

The greater enzyme loadings obtained with the PEI-GA compared to APTES-GA (Table 4) could be due to the PEI network having a relatively higher surface functional group density than APTES, i.e. more anchor points for GA activation and enzyme linkage. ${ }^{44}$ However, the PEI-GA method was also more prone to block the pores thus reducing the permeability of the membrane. The reduction in permeability could in some cases be considered an advantage, if a process with high reaction times is to be preferred; however, huge reductions in the water permeability are disadvantageous for continuous flow processes. In another study, the use of PEI-GA 
as an immobilization method on etched stainless steel resulted in an improvement in immobilization efficiency compared to physical adsorption, which was enzyme-dependent. ${ }^{41}$ The enzyme activity was particularly improved when employing two consecutive rounds of PEl coating and GA activation - especially with $\mathrm{NaCNBH}_{3}$ imine reduction. Furthermore, the use of PEI without GA activation did not improve immobilization yields or activity over physical adsorption, indicating the need for both agents in successful enzyme immobilization. ${ }^{41}$

\section{Membrane reuse}

Following the immobilization of ADH by physical adsorption, APTES-GA, or PEI-GA on the metal-supported ceramic membranes, an exploratory study was conducted in order to evaluate the reusability of the membranes, once the enzyme is completely inactive. While purely ceramic membranes may be cleaned from fouling by alternately soaking in acid and alkaline solutions, ${ }^{45}$ this method was not deemed viable here since the acid treatment could dissolve the $\mathrm{Cr}_{2} \mathrm{O}_{3}$-rich layer as well as $\mathrm{Y}_{2} \mathrm{O}_{3}$. Instead, the membranes were heated at $350^{\circ} \mathrm{C}$ to remove all organics including the enzyme and immobilization agents ${ }^{46,47}$ and the water permeability was measured at regular intervals up to $11 \mathrm{~h}$ (Figure 8).

For all membranes, the re-burning resulted in an increase in water permeability compared to their state after the first use for immobilized ADH catalysis, where the membranes were partially blocked by enzyme and immobilization agents (Figure 8). For the membranes initially heat-treated at $800^{\circ} \mathrm{C}$, the water permeability initially recovered faster for those where $A D H$ had been immobilized by physical adsorption, which was reasonable since no immobilization agents needed to be removed (Figure 8). For all C-HT800 membranes, the water permeability was highest after 7 hours of re-burning, after which it appeared to decrease (Figure 8). At their peak values, the water permeabilities were recovered by $129 \%, 109 \%$, and $84 \%$ of the initial value for physical adsorption, PEI-GA, and APTES-GA, respectively. For the $\mathrm{Y}_{2} \mathrm{O}_{3}$-coated membranes, the recovery of water permeability appeared to peak at 7 hours for physical adsorption only, whereas the highest water permeabilities for APTES-GA and PEI-GA were obtained at the last sample point, i.e. after 11 hours (Figure 8). At their peak values, the water permeability was recovered $105 \%, 81 \%$, and $78 \%$ of the initial value for physical adsorption, PEI-GA, and APTES-GA, respectively, following the same trend as the initially heat-treated membranes although the general level of recovery was lower.

The fact that the water permeability was regenerated past $100 \%$ for some of the membranes may be explained by introduction of additional hydroxyl groups upon exposure to moisture and subsequent heating at moderate temperatures $\left(350^{\circ} \mathrm{C}\right)$, which would in turn improve the membrane hydrophilicity resulting in higher water flux. ${ }^{48,49}$ Indeed, hydrothermal treatment has been found to significantly increase the amount of surface hydroxyl groups on YSZ. ${ }^{36,37}$ However, for the APTES-GA membranes where functionalization is dependent on surface hydroxyl groups, this water permeability improvement beyond $100 \%$ was not found. The observed slight decrease in water permeability beyond 7 hours could be due to measurement errors (single replicates).

As the water permeability reached levels close to the original by this simple recovery method, membranes were selected for a second round of $A D H$ immobilization using the same immobilization method as 
in the first round in order to evaluate the full membrane reusability potential. In general, the reduction in water permeability upon immobilization was comparable to that obtained in the first immobilization (Table 5). Generally, the performance in terms of enzyme loading and activity seemed to follow the trend of water permeability recovery observed for the membranes, namely physical adsorption > PEI-GA > APTES-GA (Table 5; Figure 8). Since this was an exploratory study, only single replicates were made and the data should therefore be interpreted with caution. Nevertheless, the data indicate that the re-burning was a viable recovery method for membranes where ADH was immobilized by physical adsorption: The enzyme loading, NADH conversion, and residual activity were similar to those obtained in the first immobilization (Table 5; Table 4). However, for the covalent immobilization methods, the immobilization yields and activity obtained in the first immobilization were not recovered in the second round. Only in the case of the Y-coated membrane re-burnt for $11 \mathrm{~h}$ at $350^{\circ} \mathrm{C}$, where ADH was immobilized APTES-GA, was the enzyme loading similar to that obtained previously (Table 5; Table 4). However, the obtained reaction time was only one third of that obtained in the first round, resulting in significantly lower substrate conversion (Table 5; Table 4). The results prove that the heat treatment at $350^{\circ} \mathrm{C}$ indeed unplugged the pores of the membrane and was efficient in removing fouling, but as a side effect the chemistry of the surface was modified as demonstrated by the different immobilization results. Possibly, residual carbon from the functionalization agents is left on the surface. Further studies of the chemical phenomena occurring during heat treatment is advisable for future work, which could also include optimization of temperature or even humidity for improving the thermal regeneration procedure. Alternatively, alkaline surface activation could also be an option for improved immobilization as recently reported for ceramic silicon carbide membranes in a similar system. ${ }^{23}$ Importantly, future studies should include more replicates in order to draw more firm conclusions. Similarly, the mechanical stability of the membranes should be tested in a four-point bending test or similar. ${ }^{50}$

Finally, the membranes re-immobilized with ADH were used in nine consecutive reaction cycles in order to evaluate the recycling potential of the active biocatalyst (Figure 9). The highest initial substrate conversion was obtained with APTES-GA on membranes re-burnt at $350^{\circ} \mathrm{C}$ for 7 hours (Figure 9). In all cases, ADH activity decreased relatively fast. As previously found when using the same immobilization methods for ADH on silicon carbide membranes, total loss of activity was fastest for physical adsorption, while PEI-GA appeared to maintain ADH activity longest (Figure 9). ${ }^{23}$ Immobilizing enzymes on etched stainless steel, it was previously found that the bonds formed between APTES and the alloy were labile in aqueous medium, whereas PEI coating was more stable. ${ }^{41}$ Thus, although the conversions were generally lower on the recovered membranes than on the virgin ones, the data on biocatalyst recycling still indicate that the recycling potential increases when using covalent immobilization techniques, especially the PEI-GA method.

\section{Conclusions}

Microfiltration membranes were prepared by tape casting, lamination and co-sintering of a metal support structure and ceramic membrane layer. The membranes had a direct contact of the ceramic microfiltration layer 
(pore size of $0.4 \mu \mathrm{m}$ ) on the highly porous metal support (pore size of $10 \mu \mathrm{m}$ ), which gave a very high water permeability of $12000 \mathrm{~L} / \mathrm{m}^{2} \mathrm{~h}$ bar. No signs of delamination or corrosion were observed. Surface modifications of those membranes by heat treatment and $\mathrm{Y}_{2} \mathrm{O}_{3}$ impregnation show different affinity for the enzyme immobilization by physical adsorption as well as for the two covalent immobilization methods. Enzyme loading was often higher in the heat-treated membranes than in the $\mathrm{Y}$-coated ones, but coating with $0.25 \mathrm{M} \mathrm{Y}\left(\mathrm{NO}_{3}\right)_{3}$ led to adequately decreased WP and thereby increased reaction time, which in turn led to higher conversion and higher residual activity of the immobilized enzyme. The use of covalent immobilization methods (coating with PEI or grafting with APTES followed by GA activation and covalent ADH attachment) significantly improved the immobilization efficiency and resulting activity for membranes of both surface treatments. Hopefully, an exchange of buffer in future works can remedy the rapid loss of ADH activity in the biocatalyst recycling studies. ${ }^{29}$ Membrane reuse by heat treatment at $350^{\circ} \mathrm{C}$ unplugged the pores of the membrane and was efficient in removing fouling, but as a side effect the chemistry of the surface appeared to be modified as the immobilization results obtained on the virgin membranes could not be re-obtained. For biocatalyst recycling on the reused membranes, it was clear that the recycling potential increases when using covalent immobilization techniques, especially the PEI-GA method.

\section{Acknowledgments}

This work was carried out within the EnzApp project, supported by internal funding of the Department of Energy Conversion and Storage at the Technical University of Denmark. The authors would like to express their appreciation to Marianne Nielsen, Annelise Mikkelsen, and Henrik Paulsen for their technical support during sample preparation. The authors are grateful to Karl Tor Sune Thydén for his advices for the collection of highresolution SEM images.

\section{References}

1. Prazeres DMF, Cabral JMS, Enzymatic membrane bioreactors and their applications. Enzyme Microb Technol 16: 738-750 (1994).

2. Rios GM, Belleville MP, Paolucci D, Sanchez J, Progress in enzymatic membrane reactors - a review. J Memb Sci 242: 189-196 (2004).

3. Satyawali $\mathrm{Y}$, Vanbroekhoven $\mathrm{K}$, Dejonghe $\mathrm{W}$, Process intensification: The future for enzymatic processes? Biochem Eng J 121: 196-223 (2017).

4. Chakraborty S, Rusli H, Nath A, Sikder J, Bhattacharjee C, Curcio S, Drioli E, Immobilized biocatalytic process development and potential application in membrane separation: a review. Crit Rev Biotechnol 36: 43-58 (2016).

5. Luque S, Gómez D, Álvarez JR, Industrial Applications of Porous Ceramic Membranes (Pressure-Driven Processes). In Inorganic Membranes: Synthesis, Characterization and Applications; Elsevier, 2008; pp 177216.

6. Sigurdardóttir SB, Lehmann J, Ovtar S, Grivel JC, Negra M Della, Kaiser A, Pinelo M, Enzyme Immobilization 
on Inorganic Surfaces for Membrane Reactor Applications: Mass Transfer Challenges, Enzyme Leakage and Reuse of Materials. Adv Synth Catal 360: 2578-2607 (2018).

7. Van Gestel T, Sebold D, Meulenberg WA, Bram M, Buchkremer H-P, Manufacturing of new nanostructured ceramic-metallic composite microporous membranes consisting of $\mathrm{ZrO} 2, \mathrm{Al} 2 \mathrm{O} 3, \mathrm{TiO} 2$ and stainless steel. Solid State lonics 179: 1360-1366 (2008).

8. Li Z, Yang Z, Qiu N, Yang G, A sol-gel-derived $\alpha$-Al2O3 crystal interlayer modified 316L porous stainless steel to support TiO2, SiO2, and TiO2-SiO2 hybrid membranes. J Mater Sci 46: 3127-3135 (2011).

9. Zhao L, Bram M, Buchkremer HP, Stöver D, Li Z, Preparation of TiO2 composite microfiltration membranes by the wet powder spraying method. J Memb Sci 244: 107-115 (2004).

10. ZHOU S, FAN Y, HE Y, XU N, Preparation of titania microfiltration membranes supported on porous Ti-Al alloys. J Memb Sci 325: 546-552 (2008).

11. Cui Y, Liu S, Smith K, Yu K, Hu H, Jiang W, Li Y, Characterization of corrosion scale formed on stainless steel delivery pipe for reclaimed water treatment. Water Res 88: 816-825 (2016).

12. Żurek J, Wessel E, Niewolak L, Schmitz F, Kern T-U, Singheiser L, Quadakkers W., Anomalous temperature dependence of oxidation kinetics during steam oxidation of ferritic steels in the temperature range 550$650^{\circ}$ C. Corros Sci 46: 2301-2317 (2004).

13. Grabke HJ, Surface and interface segregation in the oxidation of metals. Surf Interface Anal 30: 112-119 (2000).

14. Obert R, Dave BC, Enzymatic Conversion of Carbon Dioxide to Methanol: Enhanced Methanol Production in Silica Sol-Gel Matrices. J Am Chem Soc 121: 12192-12193 (1999).

15. Luo J, Meyer AS, Mateiu R V., Pinelo M, Cascade catalysis in membranes with enzyme immobilization for multi-enzymatic conversion of CO2 to methanol. N Biotechnol 32: 319-327 (2015).

16. Marpani F, Pinelo $\mathrm{M}$, Meyer AS, Enzymatic conversion of $\mathrm{CO}$ to $\mathrm{CH} 3 \mathrm{OH}$ via reverse dehydrogenase cascade biocatalysis: Quantitative comparison of efficiencies of immobilized enzyme systems. Biochem Eng J 127: 217-228 (2017).

17. Luo J, Meyer AS, Jonsson G, Pinelo M, Fouling-induced enzyme immobilization for membrane reactors. Bioresour Technol 147: 260-268 (2013).

18. Zhou ZD, Li GY, Li Y jian, Immobilization of Saccharomyces cerevisiae alcohol dehydrogenase on hybrid alginate-chitosan beads. Int J Biol Macromol 47: 21-26 (2010).

19. Zhang H, Luo J, Li S, Wei Y, Wan Y, Biocatalytic Membrane Based on Polydopamine Coating: A Platform for Studying Immobilization Mechanisms. Langmuir 34: 2585-2594 (2018).

20. Mistler RE, Twiname ER, Tape Casting: Theory and Practice; Wiley-American Ceramic Society: Westerville, Ohio, USA, 2000.

21. Chrzan $A$, Ovtar $S$, Jasinski $P$, Chen $M$, Hauch $A$, High performance LaNi1- $x$ CoxO3- $\Delta(x=0.4$ to 0.7$)$ infiltrated oxygen electrodes for reversible solid oxide cells. J Power Sources 353: 67-76 (2017).

22. Karczewski J, Dunst KJ, Jasinski P, Molin S, High temperature corrosion and corrosion protection of porous Ni22Cr alloys. Surf Coatings Technol 261: 385-390 (2015).

23. Zeuner B, Ma N, Berendt K, Meyer AS, Andric P, Jørgensen JH, Pinelo M, Immobilization of alcohol dehydrogenase on ceramic silicon carbide membranes for enzymatic $\mathrm{CH} 3 \mathrm{OH}$ production. J Chem Technol Biotechnol 93: 2952-2961 (2018).

24. Liu Y, Li Y, Li XM, He T, Kinetics of (3-aminopropyl)triethoxylsilane (aptes) silanization of 
superparamagnetic iron oxide nanoparticles. Langmuir 29: 15275-15282 (2013).

25. Oliveira GB, Lima Filho JL, Cavalcante Chaves ME, Azevedo WM, Carvalho LB, Enzyme immobilization on anodic aluminum oxide/polyethyleneimine or polyaniline composites. React Funct Polym 68: 27-32 (2008).

26. Melander C, Tüting W, Bengtsson M, Laurell T, Mischnick P, Gorton L, Hydrolysis of maltoheptaose in flow through silicon wafer microreactors containing immobilised $\alpha$-amylase and glycoamylase. Starch/Staerke 58: 231-242 (2006).

27. Wang ZH, Jin G, Covalent immobilization of proteins for the biosensor based on imaging ellipsometry. $J$ Immunol Methods 285: 237-243 (2004).

28. Luo J, Marpani F, Brites R, Frederiksen L, Meyer AS, Jonsson G, Pinelo M, Directing filtration to optimize enzyme immobilization in reactive membranes. J Memb Sci 459: 1-11 (2014).

29. Sigurdardóttir SB, Lehmann J, Grivel JC, Zhang W, Kaiser A, Pinelo M, Alcohol dehydrogenase on inorganic powders: Zeta potential and particle agglomeration as main factors determining activity during immobilization. Colloids Surfaces B Biointerfaces 175: 136-142 (2019).

30. Lin Y, Zou D, Chen X, Qiu M, Kameyama H, Fan Y, Low temperature sintering preparation of highpermeability TiO2/Ti composite membrane via facile coating method. App/ Surf Sci 349: 8-16 (2015).

31. McBee CL, Kruger J, Nature of passive films on iron-chromium alloys. Electrochim Acta 17: 1337-1341 (1972).

32. Hou J, Dong $G, Y e ~ Y$, Chen $V$, Laccase immobilization on titania nanoparticles and titania-functionalized membranes. J Memb Sci 452: 229-240 (2014).

33. Rodrigues RC, Ortiz C, Berenguer-Murcia Á, Torres R, Fernández-Lafuente R, Modifying enzyme activity and selectivity by immobilization. Chem Soc Rev 42: 6290-6307 (2013).

34. Kallay N, Kovacevic D, Dedic, Tomasic V, Effect of Corrosion on the Isoelectric Point of Stainless Steel. Corrosion 50: 598-602 (1994).

35. Kagawa M, Omori M, Syono Y, Imamura Y, Usui S, Surface Characterization of Zirconia After Reaction with Water. J Am Ceram Soc 70: C-212-C-213 (1987).

36. Kroll S, Brandes C, Wehling J, Treccani L, Grathwohl G, Rezwan K, Highly efficient enzyme-functionalized porous zirconia microtubes for bacteria filtration. Environ Sci Technol 46: 8739-8747 (2012).

37. Hsu SK, Hsu HC, Ho WF, Yao CH, Chang PL, Wu SC, Biomolecular modification of zirconia surfaces for enhanced biocompatibility. Thin Solid Films 572: 91-98 (2014).

Aminian A, Shirzadi B, Azizi Z, Maedler K, Volkmann E, Hildebrand N, Maas M, Treccani L, Rezwan K, Enhanced cell adhesion on bioinert ceramics mediated by the osteogenic cell membrane enzyme alkaline phosphatase. Mater Sci Eng C 69: 184-194 (2016).

39. Minier M, Salmain M, Yacoubi N, Barbes L, Méthivier C, Zanna S, Pradier CM, Covalent immobilization of lysozyme on stainless steel. Interface spectroscopic characterization and measurement of enzymatic activity. Langmuir 21: 5957-5965 (2005).

40. Hoog Antink MM, Sewczyk T, Kroll S, Árki P, Beutel S, Rezwan K, Maas M, Proteolytic ceramic capillary membranes for the production of peptides under flow. Biochem Eng J 147: 89-99 (2019).

41. Caro A, Humblot V, Méthivier C, Minier M, Barbes L, Li J, Salmain M, Pradier CM, Bioengineering of stainless steel surface by covalent immobilization of enzymes. Physical characterization and interfacial enzymatic activity. J Colloid Interface Sci 349: 13-18 (2010). 
42. Foerster A, Hołowacz I, Sunil Kumar GB, Anandakumar S, Wall JG, Wawrzyńska M, Paprocka M, Kantor A, Kraskiewicz $\mathrm{H}$, Olsztyńska-Janus $\mathrm{S}$, et al., Stainless steel surface functionalization for immobilization of antibody fragments for cardiovascular applications. J Biomed Mater Res Part A 104: 821-832 (2016).

43. Nishizawa K, Nakajima M, Nabetani $H, A$ forced-flow membrane reactor for transfructosylation using ceramic membrane. Biotechnol Bioeng 68: 92-97 (2000).

44. Nayab S, Farrukh A, Oluz Z, Tuncel E, Tariq SR, Rahman HU, Kirchhoff K, Duran H, Yameen B, Design and fabrication of branched polyamine functionalized mesoporous silica: An efficient absorbent for water remediation. ACS Appl Mater Interfaces 6: 4408-4417 (2014).

45. Hofs B, Ogier J, Vries D, Beerendonk EF, Cornelissen ER, Comparison of ceramic and polymeric membrane permeability and fouling using surface water. Sep Purif Technol 79: 365-374 (2011).

46. Benito JM, Sánchez MJ, Pena P, Rodríguez MA, Development of a new high porosity ceramic membrane for the treatment of bilge water. Desalination 214: 91-101 (2007).

47. Dafinov A, Garcia-Valls R, Font J, Modification of ceramic membranes by alcohol adsorption. J Memb Sci 196: 69-77 (2002).

48. Eggen $\mathrm{CL}$, McAfee $\mathrm{PM}$, Jin $\mathrm{Y}$, Lin YS, Surface roughness and chemical properties of porous inorganic films. Thin Solid Films 591: 111-118 (2015).

49. Kogler M, Köck EM, Klötzer B, Perfler L, Penner S, Surface Reactivity of YSZ, Y2O3, and ZrO2 toward CO, CO2, and CH4: A Comparative Discussion. J Phys Chem C 120: 3882-3898 (2016).

50. Wei J, Pećanac G, Malzbender J, Review of mechanical characterization methods for ceramics used in energy technologies. Ceram Int 40: 15371-15380 (2014). 


\section{Tables}

Table 1. In an exploratory study of membrane reusability, YSZ membranes were heat-treated (re-burnt) at $350^{\circ} \mathrm{C}$ in four stages. The immobilization technique used on the virgin membranes is indicated. Each row denotes a separate replicate and ' $X$ ' indicates that the particular membrane was included in a re-burn stage. The combined heating time of the re-burn stages is displayed in the last column.

\begin{tabular}{|c|c|c|c|c|c|c|}
\hline $\begin{array}{l}\text { Membrane } \\
\text { type }\end{array}$ & $\begin{array}{l}\text { Immobilization } \\
\text { technique }\end{array}$ & $\begin{array}{c}1^{\text {st }} \text { re-burn } \\
(1 \mathrm{~h})\end{array}$ & $\begin{array}{c}2^{\text {nd }} \text { re-burn } \\
(1 \mathrm{~h})\end{array}$ & $\begin{array}{c}3^{\text {rd }} \text { re-burn } \\
(5 \mathrm{~h})\end{array}$ & $\begin{array}{c}4^{\text {th }} \text { re-burn } \\
(5 \mathrm{~h})\end{array}$ & $\begin{array}{c}\text { Total heating } \\
\text { time [h] }\end{array}$ \\
\hline \multirow{7}{*}{$\begin{array}{l}\text { Heat-treated } \\
\text { (C-HT800) }\end{array}$} & \multirow{2}{*}{ Physical adsorption } & $X$ & $X$ & \multirow[b]{2}{*}{$x$} & $X$ & 7 \\
\hline & & $X$ & & & $X$ & 11 \\
\hline & \multirow{3}{*}{ PEI-GA } & $x$ & $x$ & \multirow{3}{*}{$x$} & $x$ & 7 \\
\hline & & $x$ & & & $x$ & 11 \\
\hline & & $x$ & & & $x$ & 6 \\
\hline & \multirow{2}{*}{ APTES-GA } & $x$ & $x$ & \multirow{3}{*}{$x$} & $x$ & 7 \\
\hline & & $x$ & & & $x$ & 11 \\
\hline \multirow{8}{*}{$\begin{array}{l}\mathrm{Y}_{2} \mathrm{O}_{3} \text {-coated } \\
(\mathrm{C}-\mathrm{Y} 0.25 \mathrm{M})\end{array}$} & \multirow{3}{*}{ Physical adsportion } & $x$ & $x$ & & $\mathrm{X}$ & 7 \\
\hline & & $x$ & & \multirow[t]{2}{*}{$x$} & $x$ & 11 \\
\hline & & $x$ & & & $x$ & 6 \\
\hline & \multirow{3}{*}{ PEI-GA } & $x$ & $x$ & \multirow{3}{*}{$x$} & $x$ & 7 \\
\hline & & $x$ & & & $x$ & 11 \\
\hline & & $x$ & & & $x$ & 6 \\
\hline & \multirow{2}{*}{ APTES-GA } & $\mathrm{x}$ & $x$ & \multirow[b]{2}{*}{$x$} & $x$ & 7 \\
\hline & & $X$ & & & $X$ & 11 \\
\hline
\end{tabular}


Table 2. $\mathrm{Fe} / \mathrm{Cr}$ ratios obtained by EDS analysis on the as-sintered, $\mathrm{Y}_{2} \mathrm{O}_{3}$-impregnated and heat-treated samples before (original) and after 1 year of immersion in Tris-HCl buffer. The analyzed sites are illustrated on the EDS map inserted in Figure 5c for the C-HT800 membrane: bulk corresponds to areas 1-4, surface to areas 5-7 and 10, and fractured to areas 8 and 9 (the oxide layer cracked during the sample preparation for microscopy, due to the shrinkage of the epoxy resin embedding the samples). Standard deviations represent variations between different measurements. Superscript letters ( $a, b, c)$ indicate significant difference between the values for each parameter $(p<0.05)$.

\begin{tabular}{ccccccc}
\hline & \multicolumn{3}{c}{ Fe/Cr ratio (original) } & \multicolumn{3}{c}{ Fe/Cr ratio (1 year) } \\
\hline & Bulk & Surface & Fractured & Bulk & Surface & Fractured \\
\hline as-sintered & $3.5 \pm 0.1^{\mathrm{a}}$ & $3.6 \pm 0.2^{\mathrm{a}}$ & $3.6 \pm 0.2^{\mathrm{a}}$ & $3.4 \pm 0.1^{\mathrm{a}}$ & $3.5 \pm 0.1^{\mathrm{a}}$ & $3.7 \pm 0.1^{\mathrm{a}}$ \\
\hline C-Y0.25M & $3.4 \pm 0.1^{\mathrm{a}}$ & $3.5 \pm 0.1^{\mathrm{a}}$ & $/$ & $3.7 \pm 0.5^{\mathrm{a}}$ & $3.6 \pm 0.2^{\mathrm{a}}$ & $3.5 \pm 0.3^{\mathrm{a}}$ \\
\hline C-HT800 & $3.6 \pm 0.1^{\mathrm{a}}$ & $0.7 \pm 0.4^{\mathrm{c}}$ & $1.0 \pm 0.1^{\mathrm{bc}}$ & $3.5 \pm 0.1^{\mathrm{a}}$ & $1.4 \pm 0.3^{\mathrm{b}}$ & $1.4 \pm 0.3^{\mathrm{b}}$ \\
\hline
\end{tabular}


Table 3. Data on water permeability (WP), immobilization efficiency including amount of immobilized enzyme and enzyme loading yield (ELY), reaction time, NADH conversion, and residual activity as compared to the free enzyme when immobilizing $A D H$ by physical adsorption on metal-supported ceramic membranes as-sintered, heat-treated, or coated with varying concentrations of $\mathrm{Y}\left(\mathrm{NO}_{3}\right)_{3}$. Standard deviation of duplicates (triplicates for as sintered) is given. Superscript letters $(a, b, c)$ indicate significant difference between the values for each parameter $(p<0.05)$.

\begin{tabular}{lccccc}
\hline & As-sintered & C-HT800 & C-Y0.05M & C-YO.10M & C-Y0.25M \\
\hline Initial WP [L/(m ${ }^{2}$ h bar $\left.)\right]$ & $12000 \pm 1300^{\mathrm{b}}$ & $15300 \pm 800^{\mathrm{a}}$ & $13000 \pm 1200^{\mathrm{b}}$ & $14000 \pm 500^{\mathrm{ab}}$ & $7800 \pm 250^{\mathrm{c}}$ \\
\hline $\begin{array}{l}\text { Reduction in WP after } \\
\text { immobilization [\%] }\end{array}$ & $52 \pm 5^{\mathrm{a}}$ & $36 \pm 2^{\mathrm{b}}$ & $55 \pm 5^{\mathrm{a}}$ & $52 \pm 1^{\mathrm{a}}$ & $58 \pm 4^{\mathrm{a}}$ \\
\hline $\begin{array}{l}\text { Enzyme immobilized } \\
{\left[\mathrm{mg} / \mathrm{m}^{2}\right]}\end{array}$ & $114 \pm 51^{\mathrm{a}}$ & $109 \pm 10^{\mathrm{a}}$ & $133 \pm 31^{\mathrm{a}}$ & $157 \pm 1^{\mathrm{a}}$ & $91 \pm 9^{\mathrm{a}}$ \\
\hline ELY [\%] & $28 \pm 12^{\mathrm{a}}$ & $23 \pm 2^{\mathrm{a}}$ & $29 \pm 6^{\mathrm{a}}$ & $33 \pm 0.3^{\mathrm{a}}$ & $17 \pm 1^{\mathrm{a}}$ \\
\hline Reaction time [s] & $86 \pm 6^{\mathrm{a}}$ & $90 \pm 1^{\mathrm{a}}$ & $68 \pm 18^{\mathrm{a}}$ & $67 \pm 7^{\mathrm{a}}$ & $236 \pm 23^{\mathrm{b}}$ \\
\hline NADH conversion [\%] & $19 \pm 2^{\mathrm{a}}$ & $13 \pm 1^{\mathrm{a}}$ & $17 \pm 1^{\mathrm{a}}$ & $17 \pm 5^{\mathrm{a}}$ & $41 \pm 5^{\mathrm{b}}$ \\
\hline Residual activity, $\eta[\%]$ & $25 \pm 5^{\mathrm{a}}$ & $16 \pm 1^{\mathrm{a}}$ & $22 \pm 1^{\mathrm{a}}$ & $19 \pm 6^{\mathrm{a}}$ & $46 \pm 6^{\mathrm{b}}$ \\
\hline
\end{tabular}


Table 4. Data on water permeability (WP), immobilization efficiency including amount of immobilized enzyme and enzyme loading yield (ELY), reaction time, NADH conversion, and residual activity (i.e. immobilized activity compared to free enzyme activity, n) for ADH immobilized by physical adsorption, PEI-GA, or APTES-GA on metal-supported ceramic membranes, which were either heat-treated (C-HT800) or $\mathrm{Y}_{2} \mathrm{O}_{3}$-coated with $0.25 \mathrm{M} \mathrm{Y}\left(\mathrm{NO}_{3}\right)_{3}(\mathrm{C}-\mathrm{YO} .25 \mathrm{M})$ prior to immobilization. Data on physical adsorption are from Table 3. For immobilization via PEI-GA on $\mathrm{Y}_{2} \mathrm{O}_{3}$-coated membranes, the PEI concentration was optimized as part of the study, and only single replicates were made. All other experiments were carried out in duplicates. Superscript letters indicate significant difference between values for each parameter $(p<0.05)$.

\begin{tabular}{|c|c|c|c|c|c|c|c|c|}
\hline \multirow{3}{*}{$\begin{array}{l}\text { Membrane } \\
\text { PEI conc. }[\% \mathrm{w} / \mathrm{v}]\end{array}$} & \multicolumn{2}{|c|}{ Physical adsorption } & \multicolumn{2}{|c|}{ APTES-GA } & \multicolumn{4}{|c|}{ PEI-GA } \\
\hline & \multirow[t]{2}{*}{ C-HT80O } & \multirow[t]{2}{*}{$C-Y 0.25 M$} & \multirow[t]{2}{*}{ C-HT800 } & \multirow[t]{2}{*}{$C-Y 0.25 M$} & \multirow{2}{*}{$\begin{array}{c}\mathrm{C}-\mathrm{HT} 800 \\
0.1 \% \\
\end{array}$} & \multicolumn{3}{|c|}{$C-Y 0.25 M$} \\
\hline & & & & & & $0.1 \%$ & $0.01 \%$ & $0.001 \%$ \\
\hline $\begin{array}{l}\text { Initial WP } \\
{\left[\mathrm{L} /\left(\mathrm{m}^{2} \mathrm{~h} \text { bar }\right)\right]}\end{array}$ & $\begin{array}{c}15300 \pm \\
800^{\mathrm{a}}\end{array}$ & $7800 \pm 250^{c}$ & $\begin{array}{c}13200 \pm \\
800^{\mathrm{b}}\end{array}$ & $7900 \pm 150^{c}$ & $\begin{array}{c}13200 \pm \\
550^{\mathrm{b}}\end{array}$ & $8000^{c}$ & $8300^{c}$ & $7650^{c}$ \\
\hline $\begin{array}{l}\text { Reduction in WP after } \\
\text { immobilization [\%] }\end{array}$ & $36 \pm 2^{d}$ & $58 \pm 4^{c}$ & $62 \pm 1^{c}$ & $87 \pm 3^{a}$ & $72 \pm 3^{b}$ & $94^{a}$ & $86^{a}$ & $86^{a}$ \\
\hline $\begin{array}{l}\text { Enzyme immobilized } \\
{\left[\mathrm{mg} / \mathrm{m}^{2}\right]}\end{array}$ & $109 \pm 10^{c}$ & $91 \pm 9^{c}$ & $252 \pm 23^{a}$ & $173 \pm 21^{b}$ & $252 \pm 17^{a}$ & $290^{a}$ & $283^{a}$ & $271^{a}$ \\
\hline ELY [\%] & $23 \pm 2^{d}$ & $17 \pm 1^{d}$ & $49 \pm 4^{b}$ & $38 \pm 4^{c}$ & $53 \pm 2^{\mathrm{ab}}$ & $58^{a}$ & $58^{\mathrm{a}}$ & $56^{a}$ \\
\hline Reaction time [s] & $90 \pm 1^{d}$ & $236 \pm 23^{c}$ & $119 \pm 6^{d}$ & $686 \pm 35^{b}$ & $97 \pm 4^{d}$ & $1095^{a}$ & $592^{\mathrm{b}}$ & $603^{b}$ \\
\hline NADH conversion [\%] & $13 \pm 1^{c}$ & $41 \pm 5^{b}$ & $37 \pm 1^{b}$ & $90 \pm 7^{a}$ & $44 \pm 1^{b}$ & $98^{\mathrm{a}}$ & $86^{a}$ & $87^{a}$ \\
\hline Residual activity, $\eta$ [\%] & $16 \pm 1^{c}$ & $46 \pm 6^{b}$ & $43 \pm 1^{b}$ & $97 \pm 7^{\mathrm{a}}$ & $51 \pm 0.3^{b}$ & $105^{a}$ & $92^{\mathrm{a}}$ & $94^{a}$ \\
\hline
\end{tabular}


Table 5. Reduction in water permeability (WP), enzyme loading, reaction time (i.e. filtration time), NADH conversion, and residual activity (i.e. immobilized activity compared to free enzyme activity, $\eta$ ) in the second immobilization on metalsupported ceramic membranes that had been re-burnt at $350^{\circ} \mathrm{C}$ to remove the first immobilization. The same immobilization was employed in the first and second immobilization. As this was an explorative study, only one replicate was made per observation.

\begin{tabular}{lcccccc}
\hline Membrane surface treatment & \multicolumn{4}{c}{ C-HT800 } & \multicolumn{3}{c}{ C-Y0.25M } \\
\hline Immobilization method & Phys. ads. & PEI-GA & APTES-GA & APTES-GA & APTES-GA & APTES-GA \\
\hline Re-burning time [h] & 11 & 11 & 11 & 7 & 11 & 7 \\
\hline WP reduction after immobilization [\%] & 52 & 64 & 55 & 65 & 72 & 75 \\
Enzyme immobilized [mg/m²] & 115 & 83 & 11 & 69 & 162 & 93 \\
ELY [\%] & 28 & 20 & 3 & 16 & 36 & 21 \\
Reaction time [s] & 66 & 137 & 102 & 68 & 235 & 271 \\
NADH conversion [\%] & 12 & 11 & 7 & 13 & 24 & 32 \\
Residual activity, $\eta[\%]$ & 15 & 14 & 57 & 26 & 27 & 36 \\
\hline
\end{tabular}




\section{Figures}

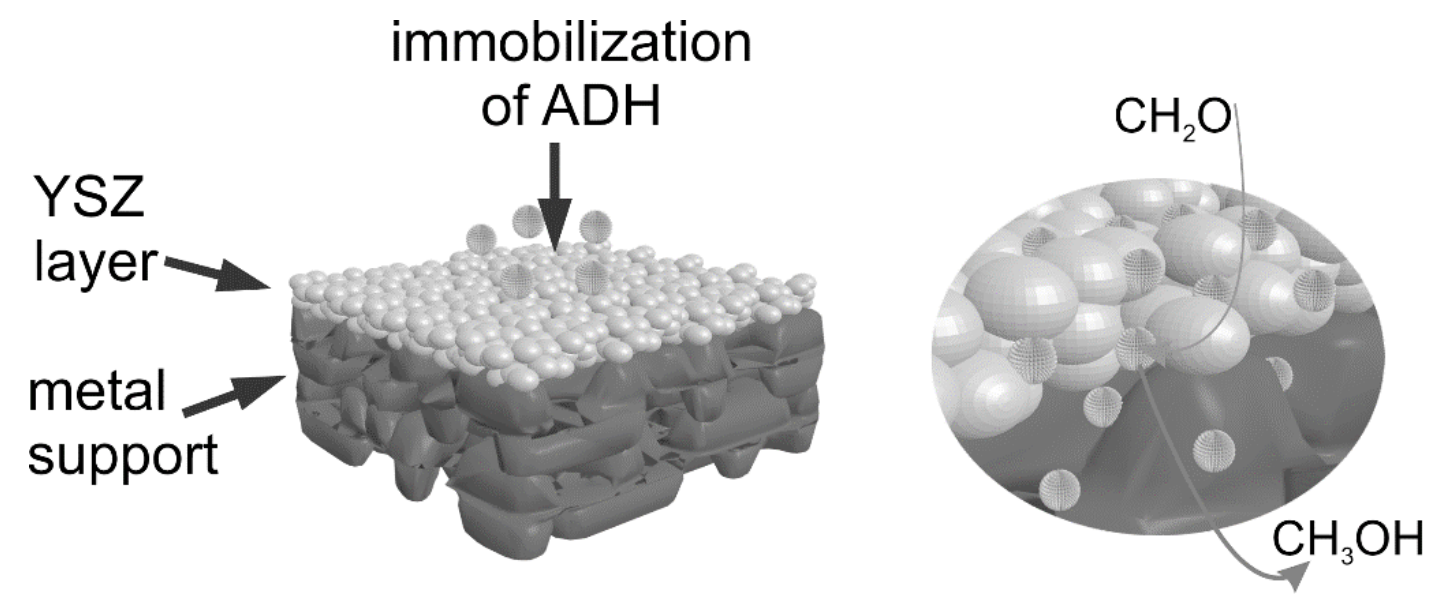

Figure 1. Schematics illustration of the membrane design, including type of layers (materials), enzyme immobilization, substrate and product flow (formaldehyde converted to methanol). 


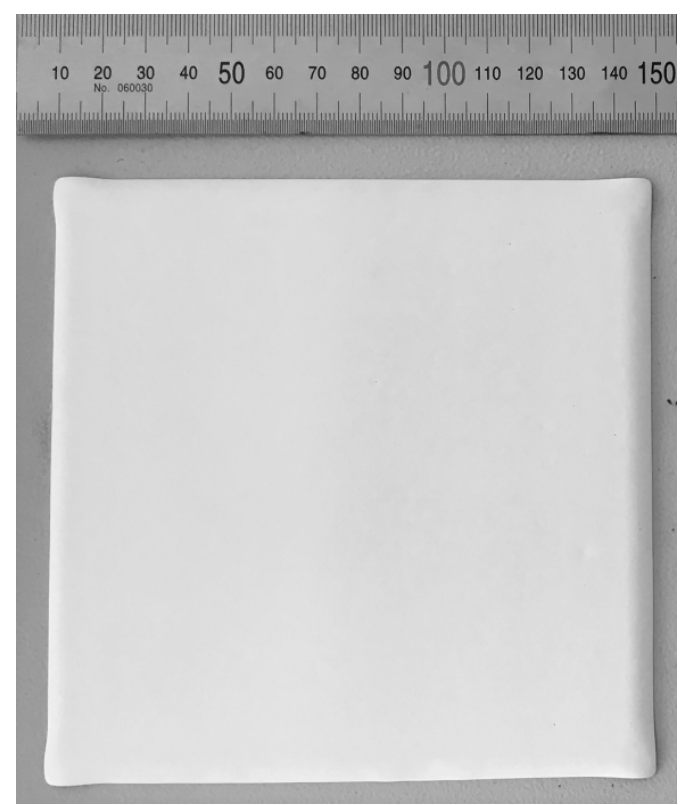

Figure 2. Picture of a sintered $140 \times 140 \mathrm{~mm}^{2}$ metal supported membrane. 


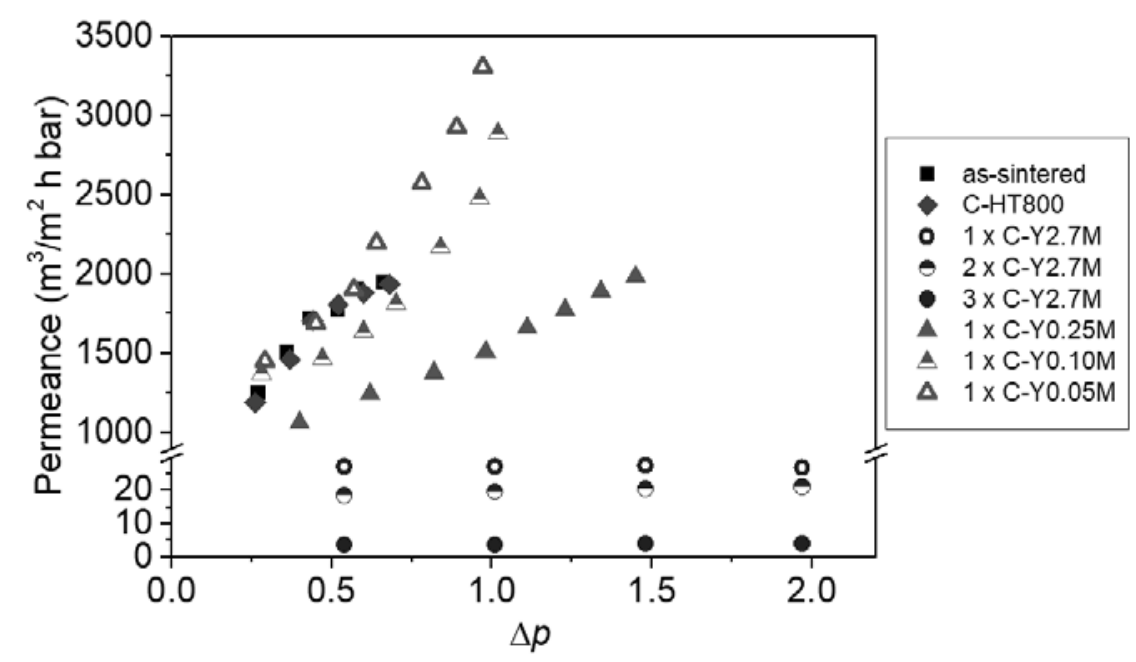

Figure 3. Gas permeance as a function of applied pressure gradient for different membranes: as-sintered, heat-treated (CHT800) and yttria impregnated membranes ( $a \times C-Y b M)$, where $a$ is the number of impregnation steps and $b$ is the concentration of the $\mathrm{Y}\left(\mathrm{NO}_{3}\right)_{3}$ solution. 


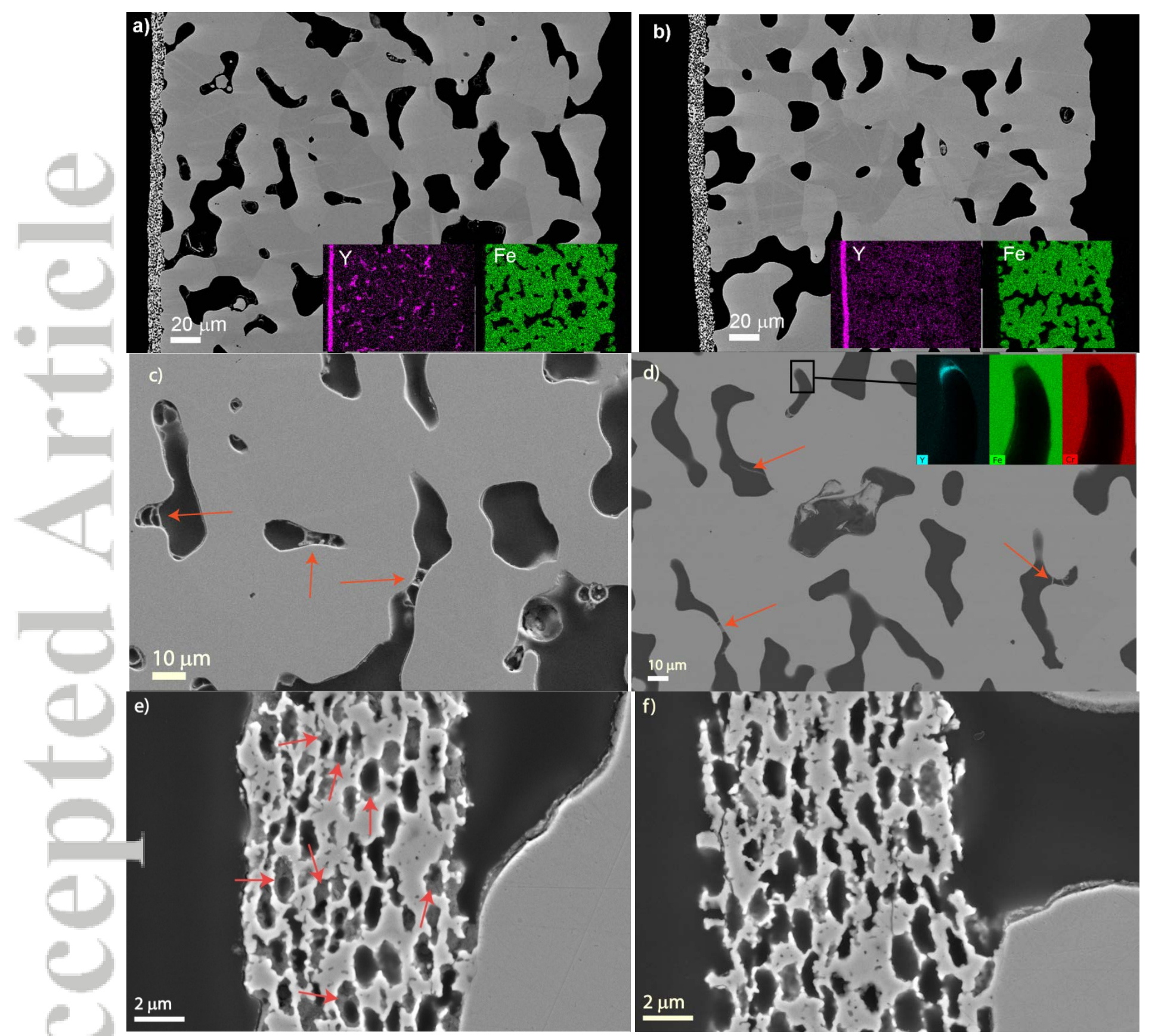

Figure 4: SEM cross sections and EDS maps (inserts) of the metal supported membranes (as-sintered) after the $\mathrm{Y}_{2} \mathrm{O}_{3}$ impregnation at different $Y\left(\mathrm{NO}_{3}\right)_{3}$ concentration: $a, c$, e) $2.7 \mathrm{M}$ and $\left.b, d, f\right) 0.25 \mathrm{M}$. $Y$ (purple) and Fe (green) distributions are shown in the insets of $a$ and $b$. The enlarged microstructures of the metal support in (b) and (d) (with inset in (d) showing $Y, F e$, and Cr EDS maps). The enlarged microstructures of the YSZ layer in (e) and (f). Arrows in (b, d) point to $\mathrm{Y}_{2} \mathrm{O}_{3^{-}}$ 
bridges, in (e) to $\mathrm{Y}_{2} \mathrm{O}_{3}$ segregation. The dark phase represents pores and the bright phase is the membrane with a thick metal support and a thin YSZ layer. 


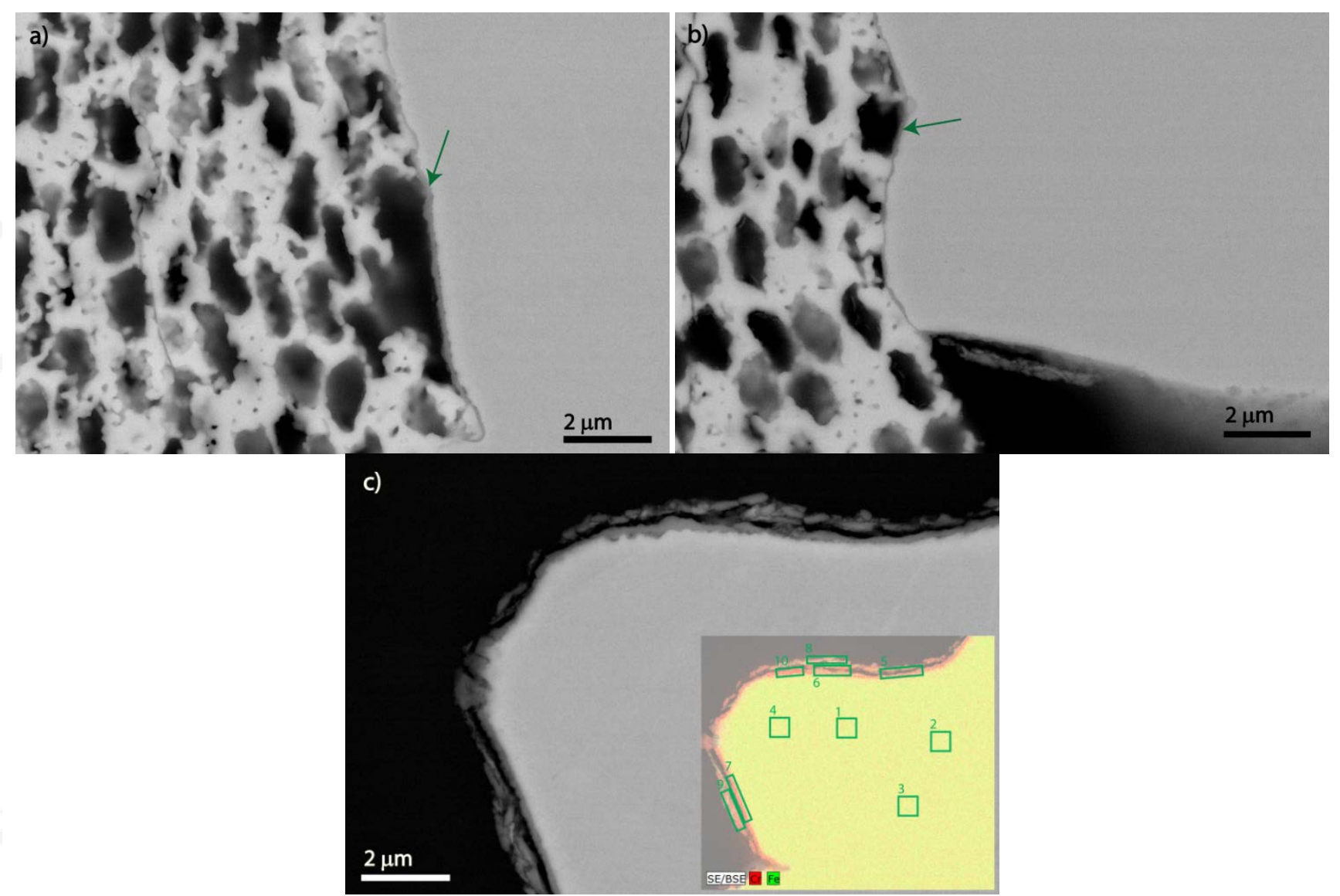

Figure 5: SEM micrographs of heat-treated samples (C-HT800): a) original and b) after 1 year in the Tris-HCl buffer solution (arrows point to the $\mathrm{Cr}_{2} \mathrm{O}_{3}$-rich layer), and c) micrograph with EDS map (Cr and Fe) superimposed on SEM picture of the heat-treated metal support with EDS analysis areas marked by green profiles. 

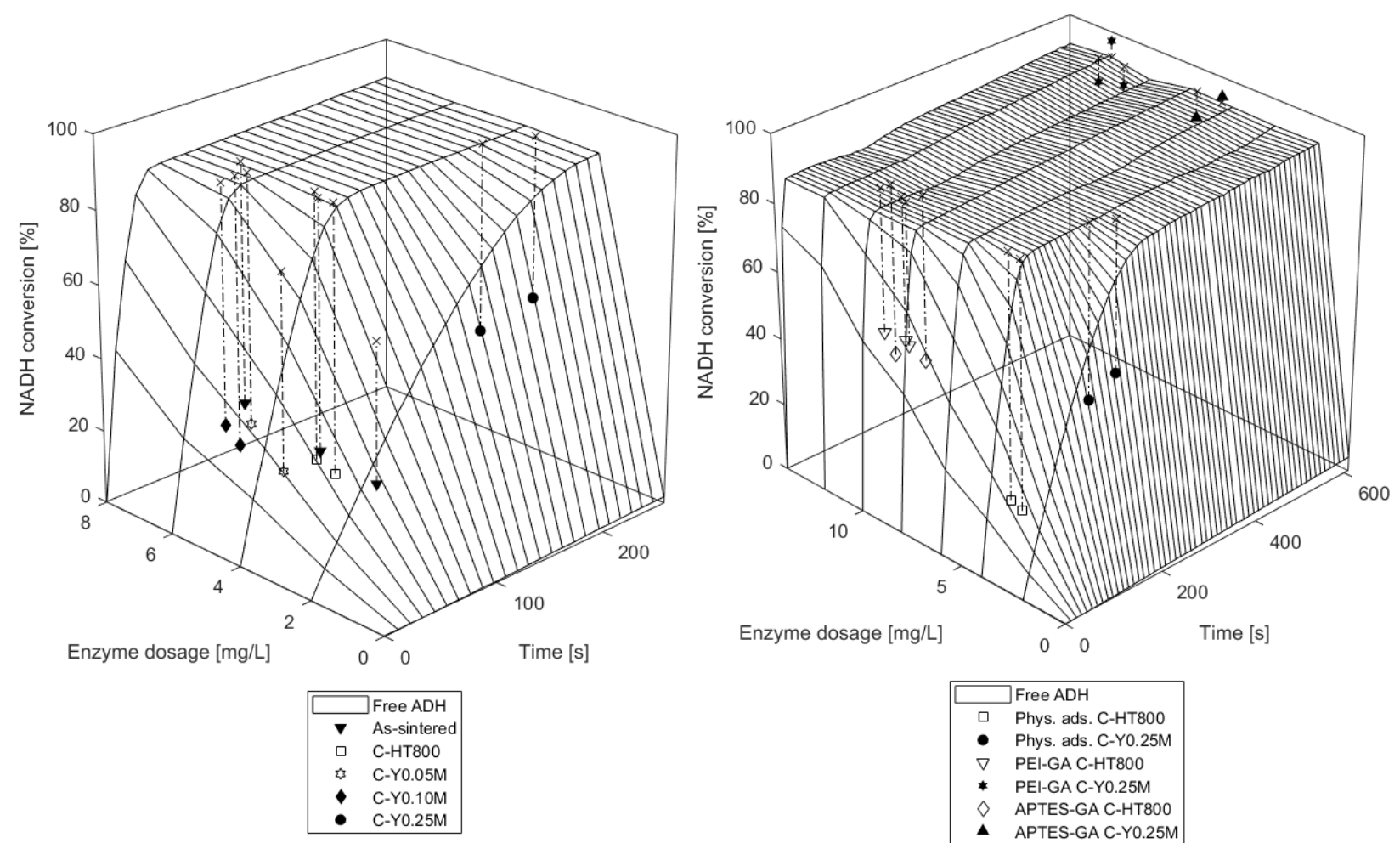

Figure 6. Activity of free ADH given as NADH conversion, $X$ (mesh). Free $A D H$ was used at concentrations of $0-14 \mathrm{mg} / \mathrm{L}$.

Absorbance was measured every 11 seconds, i.e. data points resulting from triplicates are at all the line intersections in the mesh. For each metal-supported ceramic membrane with immobilized ADH, a certain set of enzyme loading (enzyme dosage) and reaction time was recorded alongside a resulting NADH conversion catalyzed by the immobilized ADH, $X_{i m m}$ (Table 3; Table 4). The NADH conversion obtained with free $A D H\left(X_{\text {free }}\right)$ was interpolated for all these combinations of reaction time and enzyme loading obtained with immobilized $A D H$ (black crosses). From that, the residual activity $\eta=$ $\left(X_{\text {imm }} / X_{\text {free }}\right) \times 100 \%$ was calculated; the dotted-dashed lines indicate the distance between $X_{\text {free }}$ (black crosses) and $X_{\text {imm }}$ (filled symbols) as a guide to the eye. Left: Physical adsorption on as-sintered and all surface-treated membranes. Right: All three immobilization methods (physical adsorption, APTES-GA, and PEI-GA) on selected membranes (C-HT80O and C$0.25 \mathrm{M})$. For the two APTES-GA (C-YO.25M) replicates and for one replicate of PEI-GA (C-YO.25M), the reaction time was set to the maximum time measured in the free enzyme assay (609 s), although the actual reaction times were 661, 710, and 1095 seconds, respectively. These data points are on a part of the curve, where time has little effect on the NADH conversion level. 


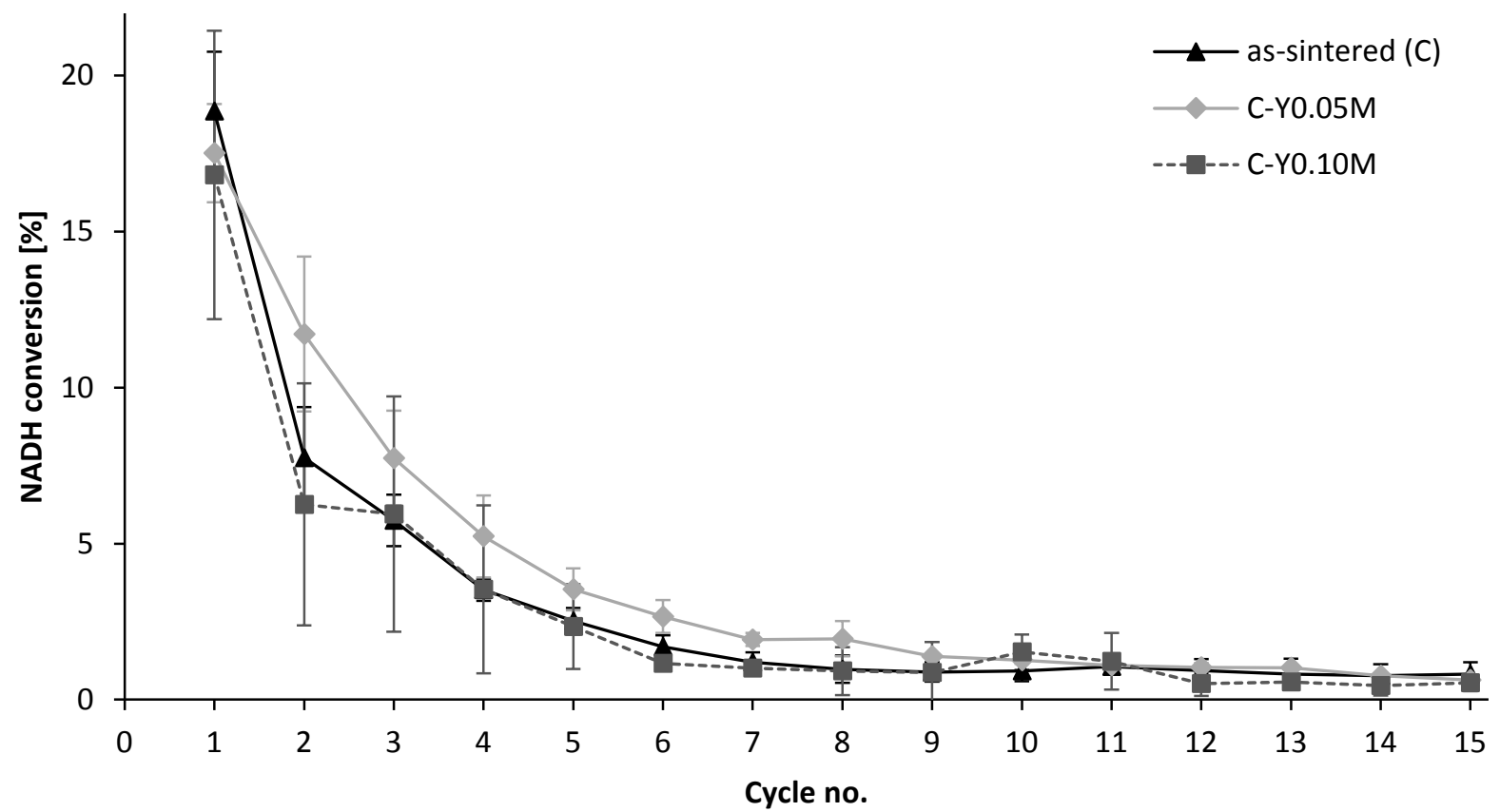

Figure 7. Activity of immobilized ADH given as NADH conversion (\%) over 15 cycles of reaction. ADH was immobilized by physical adsorption on metal-supported YSZ membranes: as-sintered or coated with 0.05-0.10 M Y (NO3) $)_{3}$ Error bars indicate standard deviation of duplicate samples (triplicates for as-sintered). The waiting time between each cycle was approx. 2 minutes, and the reaction time 1.1-1.4 minutes (Table 3). 

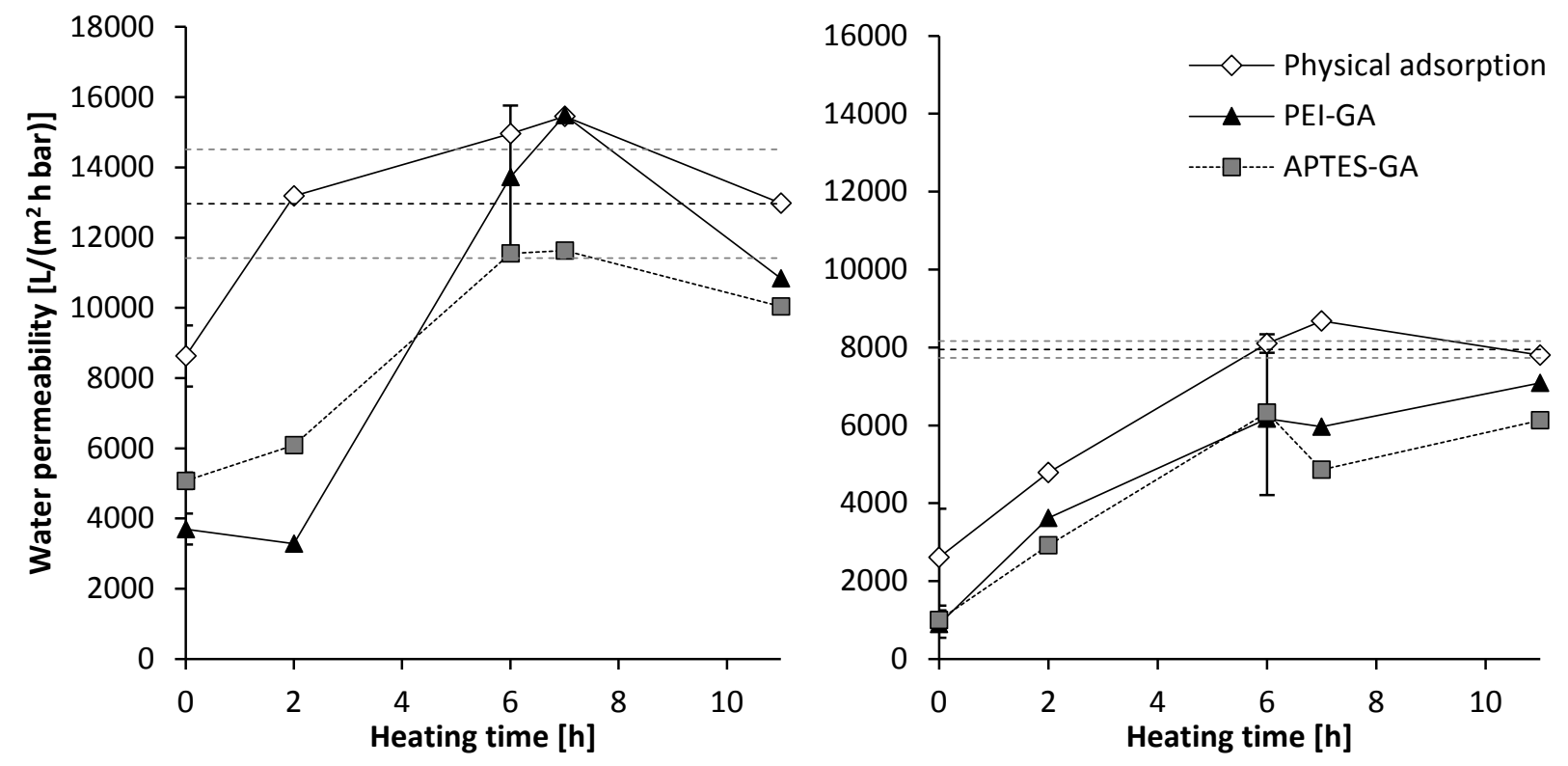

Figure 8. Water permeabilities obtained after re-burning at $350{ }^{\circ} \mathrm{C}$ for up to 11 hours of membranes that were initially surface-modified by heat-treatment at $800^{\circ} \mathrm{C}$ (left; C-HT800) and by Y-coating (right; C-YO.25M) and then used for ADH immobilization by the indicated methods (physical adsorption, PEI-GA, or APTES-GA). The value at 0 hours indicates the water permeability obtained after immobilization by the indicated immobilization methods. Dashed horizontal lines indicate the average water permeability of the virgin membranes (black) and its standard deviation (grey) before functionalization and immobilization. Error bars designate standard deviations of 2-3 replicates. Where no error bars are shown, only one replicate was made. 

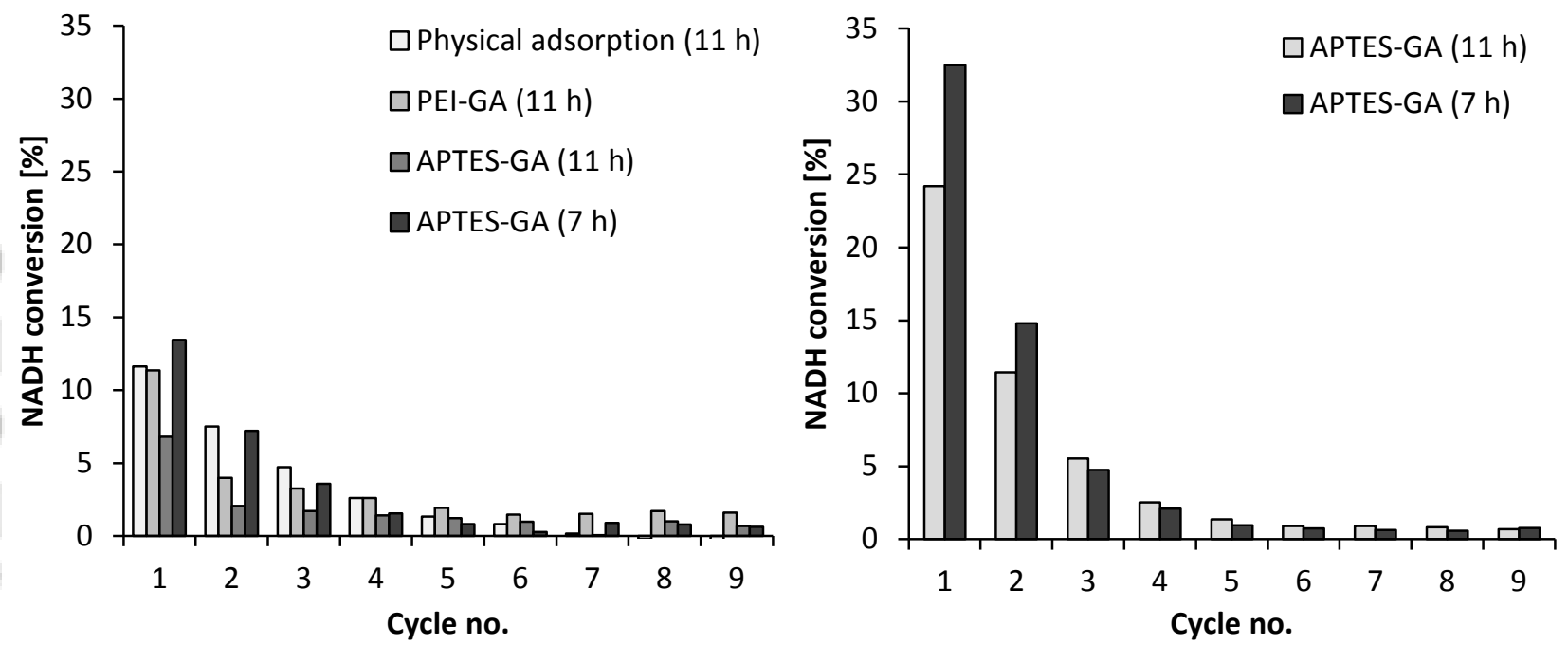

Figure 9. ADH activity measured as NADH conversion when immobilized on metal-supported YSZ membranes recovered by re-burning at $350^{\circ} \mathrm{C}$ for $7-11 \mathrm{~h}$. Originally, the membranes were surface modified either by heat treatment at $800^{\circ} \mathrm{C}($ left; $\mathrm{C}$ HT800) or by $Y$-coating with $0.25 \mathrm{M} \mathrm{Y}\left(\mathrm{NO}_{3}\right)_{3}$ (right; C-Y0.25M). The same immobilization method (physical adsorption, PEIGA, or APTES-GA) was used in both the first and second immobilization. Upon the second immobilization, the membranes with immobilized $A D H$ were re-used for 9 reaction cycles. The average reaction time ranged from 1 to 5 minutes depending on the membrane and immobilization method (see Table 5) and the waiting time between each cycle was approx. 2 minutes. Each data series represent a single replicate. 